\title{
L. J. Du Plessis as Regsdenker
}

\author{
LOURENS M. DU PLESSIS
}

Departement Regsfilosofie P.U. vir C.H.O.

\begin{abstract}
This article seeks to explain some of the outlines of the legal pbilosopby of L. J. du Plessis, witbout pretending that a meticulously coberent system of thought can be deduced from bis deverse legal writings. Mucb ratber the claim is made that bis endeavours display a marked "enviromental involvement", bence placing bis contribution in the framework of

(1) the South African jurisprudential scene of bis time, and

(2) the mainstream of twentietb-century Reformational (or Neo-Calvinist) thought.

Even though Du Plessis relies heavily on the Dooyeweerdian Pbilosopby of the Comonomic Idea, be also sbows bimself to be a profoundly original thinker at the same time. The spearbead of this originality manifests itself in the way in which bet intergrates a socto-eschatological view of reality in bis legal thought, to an extent unsurpassed by bis like-minded contemporaries.
\end{abstract}

The first part of the this article introduces Du Plessis as a jurist displaying a marked environmental sensitivity. It also attempts to contextualize bis contribution in the field of legal theory. The second part deals with the foundational lines, along which bis legal thought bad developed as well as the distinctive characteristics of bis contribution.

\section{INLEIDEND}

'n Oorsig soos hierdie is uiteraard aan bepaalde beperkinge onderhewig. Hierdie beperkinge, moet ek egter al dadelik sê, word nie deur die regsdenke van L J du Plessis self opgelê of geimpliseer nie. Du Plessis se eie visie tas so wyd as wat die menslike denke in sy begrensheid kan reik. Plek-plek open dit - juis in sy "onafheid" - perspektiewe wat 'n mens laat duisel. Du Plessis se besondere begaafdheid is maar een verklaring hiervoor. Want hy paar telkens ook sy briljante insigte met 'n deurpriemend soekende sosiaal-eskatologiese toekomsvisie (kyk veral 5 hieronder). So byvoorbeeld skryf hy (Du Plessis, 1945: 34), in die fleur sy akademiese loopbaan:

Koers, 46(1) 1981 


\section{Lourens $\mathbf{M}$. du Plessis}

"Tye verander en stelsels saam met hulle en ons behoort aan die tyd wat kom".

Wat hy hier sê, word in die praktyk van sy wetenskapsbeoefening waar. En 'n juris wat ook as 't ware die toekoms in dink, doen iets uitsonderliks. Die versoeking om analities skerpsinnig by die status quo, die hede, te vertoef, is vir juis die juris groot. As institusionele wetenskappers neig juriste - van "links" sowel as van "regs" - al te dikwels tot 'n benepe soort konserwatisme en status quo-isme in hulle denke. Nie $\mathrm{L}, \mathrm{J}$ du Plessis nie. Om sy regsdenke met verwysing na 'n formele juridies institusionele status quo te probeer skematiseer, sal, eksegeties gesproke, fataal wees. En juis dit kompliseer die huidige uiteensetting dermate dat ek nie durf voorgee dat hier iets meer as 'n oorsig in brë̈ trekke aangepak word nie.

Afgesien van die feit dat die huidige studie bedoel is om so 'n akkuraat moontlike al is dit beperkte - oorsig van L J du Plessis se regsdenke te gee, poog dit terselfdertyd om ook vir nie-regswetenskaplike lesers 'n insig in én Du Plessis se werken denkwyse èn die trefwydte van sy arbeid op regsgebied te gee. Vandaar die algemene agtergrondsperspektief in 2 hieronder. In 3 hieronder word, met die blootlegging van die grondslae van Du Plessis se regsdenke, die konstruksie van 'n gemeenskaplike waarderingsbasis vir nie-regswetenskaplikes én regswetenskaplikes beoog - 'n gemeenskaplike basis van waaruit ook insig in sy besondere juridiese denkmodus verkry kan word. 4 en 5 hieronder is, meer gespesialiseerd regsteoreties, op die eie-aardigheid van Du Plessis se regsdenke afgestem, in die vertroue dat dit verdere nadenke oor en 'n meer gedetailleerde oopdekking van sy besondere bydrae op regsgebied mag stimuleer.

Ek skryf oor Du Plessis as regsdenker en nie soseer as regswetenskaplike oor die algemeen nie. Indien 'n mens onder regsfilosofie nadenke vir of ten behoewe van die reg en regswetenskap met hulle eiesoortige probleme verstaan, skryf ek wel ook oor Du Plessis as regsfilosoof. 'n Regsfilosoof in die sin van 'n konsekwente sisteemdenker wat hy egter nie - ofskoon sy denke natuurlik nie geheel en al asistematies is nie. Omdat "regsdenke" en "regsdenker" egter "veiliger" terme is, volstaan ek daarmee.

Vir lesers wat meer oor die agtergrond van $\mathrm{L} J$ du Plessis se regs- en staatkundige denke te wete wil kom, beveel ek met groot vrymoedigheid die deeglike en insiggewende verhandeling van P. J.J S. Potgieter (1972) - wat ook as 'n IBC-publikasie beskikbaar is - aan. Met die breëre indelings van Potgieter is ek dit volkome eens, en ek het dan ook sy werk as 'n agtergrondgids by die skrywe van hierdie artikel 


\section{J. Du Plessis as Regsdenker.}

besonder waardevol gevind. Op die voorpunt van die tye is, na die beste van my wete, die enigste gedeë sistematiese (en ook krities simpatieke) Du Plessis-studie wat tot op hede die lig gesien het.

\section{ALGEMENE AGTERGRONDSPERSPEKTIEF}

\subsection{J. Du Plessis se geskrifte}

L. J. du Plessis maak sy debuut as skrywer oor die reg en regsteorie in 1934 (vgl Du Plessis 1934 (a) en (b) ), dit wil sê in die jaar nadat hy as professor in Staatsleer en Regte aan die PUK vir CHO benoem is en in dieselfde jaar wat hy sy LL B graad verwerf het. Sy 1934-geskrifte oor die reg is in 'n sekere sin meer staatsteoreties as regsteoreties van aard en moet nie los van sy vroeëre werke oor veral die staatkunde gesien word nie (kyk vir bibliografiese gegewens Potgieter 1972, 256 7). Veral 'n vroeëre verhandeling oor Calvyn se staatsteorie (Du Plessis 1932) het Du Plessis se regs- en staatkundige denke grondliggend beïnloed. Sy evaluering van Calvyn se staatsteorie teen die agtergrond van die staatspraktyk in die sestiende eeu getuig van heelwat meer as bloot 'n gedeë klassikus se skerpsinnige interpretasievermoëns; dit openbaar ook 'n skerpsinnige historiese bewussyn en ' $n$ gevoelige historiese empatie - ' $n$ inleef in ' $n$ beslissende tyd gees uit die vervloë verlede (kyk my evaluering van hierdie werk in Du Plessis 1974, 33 - 40).

Reeds in die dertigerjare skryf Du Plessis twee belangrike artikels waarin hy sy uitgangspunte oor die reg en regskwessies duidelik uitstippel. Die een artikel (Du. Plessis 1934 (b) handel oor (die verhouding tussen) staat en reg en is blykbaar die teks van sy intreerede wat hy onveranderd laat publiseer het. Hierdie artikel getuig in die eerste plek van 'n eie, heel oorspronklike interpretasie van die ontwikkeling van die Westerse regsgeskiedenis in korrelasie met sekere hooftyd perke in die Westerse staatkundige geskiedenis. Die periodiserings waarop hy die 1934artikel baseer, word in sy monografie (as 'n mens so iets a an Wikus du Plessis kan toedig!) oor die moderne staat, sewe jaar later, behou (vgl. Du Plessis 1941 (a), 3 - 20).

In die tweede plek getuig die uiteensetting in die 1934-artikel oor staat en reg van die feit dat Du Plessis toe reeds met sekere van die grondgedagtes van Herman Dooyeweerd se regs- en staatsteorie goed bekend was en dit heel knaphandig hanteer. Dit is nogal merkwaardig indien 'n mens in gedagte hou dat Dooyeweerd se magnus opus (De wijsbegeerte der wetsidee - Dooyeweerd 1935) eers in 1935 verskyn het en dat $\mathbf{L}$. J. du Plessis dus via 'n reeks verspreide en nogal uiteenlo- 


\section{Lourens M. du Plessis}

pende artikels en verhandelinge (soos Dooyeweerd 1925, 1926, 1928, 1930(a) en (b) en 1933) met die Wysbegeerte van die Wetsidee kennis moes gemaak het. Potgieter (1972, p 40) opper die moontlikheid dat hy reeds in 1919-1921 - tydens sy verblyf in Nederland - met die filosofie van Dooyeweerd in aanraking gekom het. Ek betwyfel dit egter, aangesien daar myns insiens eers sedert 1926 werklik van 'n (eie) "wysbegeerte van Dooyeweerd" sprake kan wees.

Die tweede belangrike artikel op regsgebied wat uit die dertigerjare dateer, is 'n artikel oor Calvinisme en Volkereg (1939) (wat as aanhangsel II in Du Plessis 1943 (b), p 111 - 9 opgeneem is). Hierin word die grondlyne van dit wat ek in 5.3 hieronder Du Plessis sosiologies-eskatologiese visie op die reg en regsinstellings noem, die eerste keer (klinkklaar en feitlik afgerond) uitgestippel.

Belangrik met die oog op die ontwikkeling van sy regsdenke gedurende die veertigerjare is veral sy artikel oor juridiese kousaliteit (Du Plessis 1941(a)), sy artikel oor die einde van die individualisme (ook) in die reg (Du Plessis 1944) en veral sy monografie wat hy as 'n inleiding tot die algemene regsleer of jurisprudensie aandien (Du Plessis 1943(b) ). Oor die laasgenoemde werk - sy enigste omvattende sistematiese verhandeling oor regsteoretiese kwessies - moet vervolgens die een en ander opgemerk word.

Slegs die eerste drie hoofstukke van hierdie werk bevat 'n taamlik sistematiese weergawe van die regsteoretiese of -filosofiese uitgangspunte waarop Du Plessis steun. Hierdie uitgangspunte is, oor die algemeen gesproke, sterk Dooyeweerdiaans met plek-plek egter 'n eie aanslag en nuanse (hieroor in 3 hieronder meer). Die "eienheid" oorheers egter nie. Heel oorspronklik en skerpsinnig - en eie aan L. J. du Plessis - is egter die res van die werk, waarin merkwaardige insigte rondom sy siening oor die indeling van die reg ontwikkel word. Op die besonderhede hiervan kan - ruimteonthalwe - in hierdie artikel ongelukkig nie volledig ingegaan word nie, en daar moet dus slegs met sydelingse verwysings, in terme van die beperkinge wat my eie skema oplê, volstaan word (kyk byvoorbeeld 3.6 hieronder). Du Plessis se indeling van die positiewe reg is ongetwy feld nie bo kritiek verhewe nie - dít veral vir sover hierdie indeling op 'n klassifikasie van subjektiewe regte gebaseer is. Hy openbaar 'n (myns insiens te) sterk individualistiese - 'n byna individualisties-materialistiese siening op die Privaatreg:

"Die karakter van die privaatreg is dan ook beslis individualisties; daarom neig dit steeds daartoe om die individu vry te laat en te beskerm in die beheer van sy vermoë (bedoelende materiële of stoflike vermoë) en is dit teen niks so skerp ge- 


\section{J. Du Plessis as Regsdenker.}

kant as teen belemmering van die eienaar in die beskikking oor sy eiendom nie" (Du Plessis 1943 (b), p 27 - kursief my invoeging).

Gevolglik is Privaatreg vir Du Plessis (1943(b), p 27-8) hoofsaaklik aanvullende reg - of rec̈lende reg (vgl. Van der Vyver \& Van Zyl 19.72, p 133-4) - dit wil sê ad boc-reg wat, vir sover die dwingende reg van staatsweë nie ander bepalings bevat nie, van situasie tot situasie reëlings inter partes tref. Du Plessis sien myns insiens die noue korrelasie wat daar tussen die (positiewe) reg vir die individu in terme van die regsorde in sy omvattendheid of algemeenheid bestaan, skromelik oor die hoof.

"Reg" in 'n subjektiewe sin beteken vir hom uitsluitlik 'n "reg op iets" (in casu 'n regsobjek). Daarmee negeer hy nie alleen die reg wat uit 'n reg op iets voortvloei (die sogenaamde bevoegdheid) nie - A het byvoorbeeld die reg om sy fiets te gebruik omdat hy 'n reg op sy fiets het - maar ( as gevolg van die feit dat die korrelasie tussen "die reg op ..." en die regsorde vervaag) sien hy ook nie in dat 'n objeklose "reg omdat" of "reg om te kan" (die sogenaamde kompetensie) aan die "reg op . .." (die subjektiewe reg) en die reg uit die "reg op. . ." (die bevoegdheid) ten grondslag lê nie (vgl. bv. Van der Vyver \& Van Zyl 1972, p 155, en Van der Vyver 1973, p 1238-40).

Met die voorafgaande gebreke korrespondeer eweneens sy té eng beslirywing van die aard van die vorderingsreg (Du Plessis 1943(b), p 26). Regte op sake (saaklike regte), op immateriële goedere (immateriële goedereregte) en op persoonlikheidsgoed (persoonlikheidsregte) beskou Du Plessis tereg as regte wat teenoor alle regsubjekte beskerm en bygevolg afgedwing kan word-dus as sogenaamde absolute (subjektiewe) regte. Die vorderingsreg beskou hy egter as 'n persoonlike reg in die eng sin, dit wil sê bloot 'n reg van 'n skuldeiser teenoor 'n skuldenaar wat alleen binne die grense van die persoonlike skuldverhouding beskerm word. Hy laat dus op 'n eensydige wyse die regsordelike beskerming wat die vorderingsreg teenoor derdes geniet, buite rekening (kyk ook Van der Vyver \& Van Zyl 1972, p. 199-201).

Die jare 1944 tot 1956 is, vir sover dit regsgeskrifte betref, by Du Plessis 'n tydperk van stilswye, en dít hou waarskynlik verband met die feit dat hy tussen 1946 en 1953 die aktiewe akademie tydelik vaarwel toegeroep het ten einde hom in die sake wêreld te begewe, En dan in 1956 is daar' $n$ mini ontploffing. Tot in ongeveer 1963 - die jaar waarin 'n breinoperasie bekend as 'n gewysigde frontale leukotomie op hom uitgevoer is - skryf $\mathbf{L}$. J. du Plessis aanhoudend oor 


\section{Lourens M. du Plessis}

die reg en regsprobleme. Dit begin in 1956 met 'n drietal artikels: oor die kodifikasie van ons gemene reg (Du Plessis 1956 (a)), oor skadelike repristinasies in (ons) gangbare regsbeskouings (Du Plessis 1956 (b)), en oor die regsbronne-

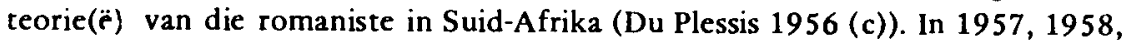
en 1959 volg verdere artikels oor juridiese vraagstukke, waaronder veelseggende (ook kritiese) waarderings van die belang van Dooyeweerd se regsfilosofie met die oog op konkrete regsprobleme in Suid-Afrika (bv. Du Plessis 1957 (b) en 1958(a)) (laasgenoemde moet saamgelees word met 1957(a)), 'n Engelse artikel oor juridiese kousaliteit (Du Plessis 1958(b)) en 'n artikel oor die regsteoretiese implikasies van staatlike soewereiniteit (Du Plessis 1959 (b)). Uit hierdie tvdvak dateer ook sy bekende regsleerdiktate (Du Plessis 1956/57)

Die stroom van publikasie droog ná 1960 nie op nie. Tog is 1960 in 'n sekere sin as 'n (ten minste stilistiese) waterskeidingsjaar aan te merk. In Du Plessis se publikasies ná 1960 word 'n mens dikwels getuie van die verbete stryd van 'n groot gees wat hom uit die goiingsakke van middelmatigheid probeer loswoel. En dit gebeur met rukke en stote. Hy begin al hoe meer fragmentaries skryf. Die heldere insigte en diep stof tot nadenke word as enkele duidelike ligbakens in sy geskrifte versprei. Tussendeur is daar steeds 'n samehangende lyn van argument en veral skerpsinnige interpretasies en waarderings van die geskrifte van andere. Die tipiese ruimheid van visie word egter vir die enkele sin of paragraaf gereserveer - en juis daarom tref dit 'n mens telkens soos 'n vuishou tussen die oë en laat dit jou onmagtig verleë. In 'n inleiding tot 'n diktaat vir LL B-studente maak Du Plessis (1961 (b), p 1) byvoorbeeld die volgende kursoriese opmerking:

"Reeds meermale het ek dit populêr en enigsins simplisties so uitgedruk dat ons ons Skrifgeloof moet vervleg met die positiewe elemente van die Ewolusie-leer vanaf Genesis en van die Kommunisme bv. Openbaring en van die Barthianisme deur die Skrif as geheel".

Hierdie opmerking maak hy in die lig van sy voorneme om aan Dooyeweerd se "hoofsaaklik negatiewe houding ... teen die ... skolastiek en die humanisme 'n meer positiewe wending te gee, deur onder andere ook die meer moderne geestestrominge en kultuurprestasies te integreer in die Calvanisties-Afrikaanse Skrifgeloof'. Inderdaad 'n hele mondvol - en dìt in twee enkele sinne!

Uit die tydvak ná 1961 dateer slegs twee tydskrifartikels - een oor wetgewersoewereiniteit (Du Plessis 1960(f) ) en een oor die natuurbegrip in die Regsfilosofie (Du Plessis 1965). Die res van Du Plessis se latere publikasies bestaan hoofsaaklik uit klasdiktate (waaruit onder andere blyk dat ook 'n nuwe belangstelling in 


\section{J. Du Plessis as Regsdenker.}

Regsvergelyking ontgin word) (Du Plessis 1960(c), (d) en (c) en 1961(b), (c) er (d) ). Dan is daar natuurlik ook nog drie betekenisvolle briewe (Du Plessis 1960 (a) en (b) en 1961(a) ) en twee manuskripte (die een in Engels) van onvoltooide proefskrifpogings (Du Plessis 1961(e)en 1962). Oor hierdie briewe en manuskripte aanstons meer.

Die wending ná 1960 is sekerlik in 'n mate uit Du Plessis se persoonlike omstandighede te verklaar. Die verhewiging van sy drankprobleem en die daarmee gepaardgaande (persoonlikheids-) "eccentricities" en "vagaries", soos Du Plessis (1960(b), p 16 en 1961(e), p 6) - wat terloops ook in sy selfkritiek en -evaluasie as 'n buitengewone groot gees uitmunt - dit self by geleentheid noem, vorm maar een onderdeel van sy totale persoonlike (probleem-) situasie. Die vaste wete dat sy grootste visie oor reg en staat steek hou - wáár is - en deur 'n "slapende" Afrikaner-"establishment" - met sy, na Du Plessis (1960(b), p 1) se mening, benepe en heerssugtige "veronderstelde volksleiers" - geignoreer word, dra miskien in die eerste plek tot sy ontgogeling by - 'n ontgogeling wat gaandeweg daartoe gelei het dat "sy waardering van homself teenoor die buitewêreld nie meer normaal was nie" (Potgieter 1972, p 18). Dit wil egter nie sê dat hy sonder meer sy "vertroue" op sy "persoonsgeregtigheid" gaan stel nie (Du Plessis 1960(b), p 17) inteendeel! Du Plessis bly - ook in sy regsgeskrifte - getrou aan dít wat hy deurentyd geglo het. En ofskoon hy hierdie geloof - in sy geskrifte - al hoe meer fragmentaries verwoord, skryf hy nog geensins onsamehangend of onverstianbaar nie. Dit is meer 'n geval van (soos hy sy "lewensbeleid" aan J. P van der Spuy verduidelik) (Du Plessis 1960(b), p 17):

" 'Ek slinger maar ek hou koers', omdat ek 'die rots ken uit wie ek gekap is'."

Dat Du Plessis selfs teen 1962 nog in staat was om sy eenheidsvisie op veral die reg èn te behou èn te verwoord, blyk onder andere uit sy twee proefskrifpogings (Du Plessis 1961(e) en 1962). Dic werklike dryf- en daadkrag om hierdie twee werke te voltooi het miskien ontbreek, ja, maar die intellektuele spankrag om sinvol en met insig te skryf bly ongeskonde - soos onder andere uit die aanhangsel tot hierdie artikel behoort te blyk (kyk ook 4 hieronder).

- Die drie briewe waarna ek voorheen verwys het, is van onskatbare waarde vir sover hulle tot die ontsluiering van die grondslae van sekere van sy denkresultate bydra. Die brief aan J.P. van der Spuy (Du Plessis 1960(b)) - waarna reeds verwys is en waarin Du Plessis die redes vir sy bedanking uit die Afrikaner-Broederbond ('n organisasie waarvan hy by geleentheid Uitvoerende Raadvoorsitter was) uiteensit - 


\section{Lourens M. du Plessis}

werp meer lig op Du Plessis se persoonlike omstandighede en sy aandeel in die Afrikaner se vryheidstryd. Sy skrywes aan H.G. Stoker en The Soutb A frican Law Journal (Du Plessis 1960(a) en 1961(a) onderskeidelik), daarenteen, bevat heelwat opmerkings van algemeen filosofiese en regsteoretiese belang. Op albei hierdie laasgenoemde skrywes word later dus vollediger teruggekom.

\subsection{Du Plessis se visie op die Suid-Afrikaanse reg en regskultuur}

Du Plessis se regsgeskrifte openbaar - soos die meeste van sy ander geskrifte - 'n sterk "omgewingsgebondenheid". Nooit ontglip die vraagstukke van sy eie tyd en kultuur sy deurdringende aandag nie. Daarom bemoei hy hom ook voortdurend met juridiese aktualiteite - met konstitusionele hervorming (Du Plessis 1934 (a) ), met die kodifikasie van ons reg (Du Plessis 1956(a)), met skadelike repristinasies in gangbare beskouings oor: sowel die staatlike as die kerkreg (Du Plessis 1956(b)), met regsbronneteorieë (Du Plessis 1956(c)), met die implikasies van Dooyeweerd se regsfilosofie vir "ons Suid-Afrikaanse regsteoretiese grondbegrippe" (Du Plessis 1957(b)) sowel as vir "die geldende en wordende publieke reg ook met betrekking tot Suid-Afrika in sy wêreldverband" (Du Plessis 1962) en les bes ook met 'n vraagstuk soos juridiese kousaliteit (Du Plessis 1941(b) en 1958(b)). Hy skryf dus vanuit sy tyd oor sy tyd (en selfs oor die toekoms - vgl. bv. Du Plessis 1943(b) p 111-9, en 1944), maar nooit laat hy hom verlei om selfgenoegsaam in die geborgenheid van die status quo (finaal) te arriveer nie.

Du Plessis het die kernmomente van die Afrikaner se bevrydingstryd gedurende die dertiger-, veertiger- en vyftigerjare aktief - en as een van die leidende Afrikanernasionaliste - meegemaak. Op regsgebied kulmineer hierdie stryd in 'n strewe om die onvervalste en "onbesoedelde" Romeins-Hollandse reg - die Wes-Europese basis van ons regstelsel - in ere te herstel, deur dit veral van die invloede van die "vreemde" Engelse reg te bevry. Met hierdie "vryheidstryd" op regsgebied kon Du Plessis as deurwinterde Calvinis hom egter nie ongekwalifiseerd versoen nie, want té veel "skadelike repristinasies" in die Romeins-Hollandse reg en regsteorie kortwiek 'n prinsipicel suiwer analise van en regspolities ideële visie op die (ook "wordende") eie Suid-Afrikaanse reg.

"Vir my gevoel . . . is primêr die werklike dinge en mense, stof, energie, bloed, lewe, drang en daad", skryf Du Plessis (1957(a), p 145) op een plek - in 'n ietwat ander verband - en daarom, gesien teen die agtergrond van sy konkrete historiese bewussyn, kan hy nie vrede vind met die gedagte wat die lewende Suid-Afrikaanse reg sy enigste of selfs aktueelste uitdrukking in 'n enigermate vervloë RomeinsHollandse tradisie moet vind nie. Veelseggend is byvoorbeeld sy kritiek op die - 
veral in terme van die Romeins-Hollandse ideaal - hoog aangeskrewe proefskrif van J.C. de Wet (1940), wat oor die beding ten behoewe van 'n derde handel. Du Plessis toon aan dat De Wet 'n uitnemende volume - ook historiese - navorsing gedoen het om uiteindelik tot 'n relatief eenvoudige gevolgtrekking, in stryd met die beersende opvattings van die howe, te geraak en vervolg dan:

"Waarlik, hierdie berg het (met alle respek gesê) 'n muis gebaar. En intussen is die bestansreg of stamboom selfs van die muis reeds deur ander regsgeleerdes ontken of in twyfel getrek . . . Al hierdie 'lucobratio' was nie alleen onnodig nie, maar ook vrugteloos. Want nou weet ons nog nie waar ons staan nie. En dit is nie dr. De Wet se fout nie, maar van die gevolgde metode" (Du Plessis 1956(a), p 259).

'n Werklike "eie reg" is dus vir Du Plessis nie 'n gerepristineerde Romeins Hollandse reg nie maar 'n eietyds tersaaklike Suid-Afrikaanse reg - dié reg van "werklike dinge en mense ... drang en daad" - wat sy outentieke beliggaming in 'n eweneens "eie-kodifikasie" behoort te vind - dit mede met die oog op "die vooruitsig op 'n betreklike spoedige vestiging van die Republiek van Suid-Afrika, wat 'n diepgrypende omvorming van ons hele staats- en regstruktuur sal moet meebring ..." (Du Plessis 1956(a), p 257).

Sy pleidooi vir kodifikasie temper Du Plessis (1956(c), p 257) egter met die realistiese siening "dat die reg nie naastenby volledig in 'n wetboek of wette gevind kan word nie". Uigaande van hierdie vertrekpunt toon hy aan dat onder veral die romaniste in Suid-Afrika daar 'n taamlike verwarring oor die begrip "regsbron" heers, en op grond van Dooyeweerd (1930, 1933 en 1966) se regsbronneteorie ontwikkel Du Plessis dan 'n teorie, wat die feit dat "die reg nooit klaar vasgelê is nie, maar . . . voortdurend gepositiveer word" en "dat elke regsnorm se regsin deur vertolking vasgestel moet word en nie kant en klaar gegee is nie" (Du Plessis 1956(c), p 262), probeer verdiskonteer. Uitdruklike sowel as stilswyende ooreenkoms en bevel word deur hom as die vernaamste twee ontstaanbronne van die reg aangedui.

Gesien teen die agtergrond van sy belangstelling in die regsbronneteorie en sy apositivistiese, "buigsame" siening van regsbronne moet Du Plessis se pleidooi vir kodifikasie myns insiens nie begryp word as 'n pleidooi vir pogings om die wordende positiewe reg in sy dinamiese ontplooiing te stuit nie, maar veeleer as 'n soeke na 'n metode waardeur die gegewe Suid-Afrik2anse reg-in-ontplooiing momenteel in sy dinamieskonkrete eie-aardigheid vasgelê en enigermate omlyn kan word. 


\section{Lourens M. du Plessis}

Du Plessis (1956(b), p 100-1) vat sy vernaamste besware teen die gangbare regsopvattings van die eksponente van die Romeins-Hollandse of Romanistiese rigting in Suid-Afrika soos volg saam:

(i) Hulle beroep hulle - net soos die gereformeerde "Dortiste" op kerkregtelike gebied - té onkrities op die geskiedenis, sodat hulle dikwels " 'n lofwaardige voortbouing op die historiese tradisie onnodiglik verbind met skadelike repristinasies" (Du Plessis 1956(b), p 100) - "repristinasies" synde (die) "teruggang na of vashouding aan verouderde opvattinge of instellinge in stryd met die gang van die historiese beskawingsontwikkeling" en wat op "frustrasie, verwarring en mislukking, net so seer as omgekeerd rewolusie" moet uitloop (Du Plessis 1956(b), p 99).

(ii) Hulle ontken die bestaan van histories wisselende, bo-willekeurige, voor-positiewe regsbeginsels en vereenselwig die erkenning daarvan té geredelik met (slegs) die natuurregsleer.

(iii) Hulle erken slegs die bestaan van die staatlike reg as reg en verontagsaam bygevolg die (nie-staatlike) reg van ander samelewingsinstellings.

(iv) Hulle indeling van die staatlike reg is té tradisionalties Justiniaans en daarom onsistematies, want so 'n indeling van die reg berus nie "op die struktuur van die reg self soos aangepas aan die van die verskillende sosiale formasies waarbinne dit geld nie" (Du Plessis 1956(b), p 100-1 - vgl. ook 1943(b), p 25 e.v. en die bespreking in 2.1 hierbo).

(v) Die reg word nie altyd na sy unieke eie-aard nie maar veelal verwysing na "ander wetmatighede van die werklikheid" begryp.

(vi) Die werklike bestaan van regspersone word ontken en konkrete (regsubjektiewe) groepsfromasies bygevolg tot blote fiksies gedevalueer.

Ontleed 'n mens hierdie besware van Du Plessis, dan blyk dit dat hy die eksponente van die Romeins-Hollandse rigting hoofsaaklik hulle eensydige regspositivisme verwyt, dit wil sê die feit dat hulle alle "regsmaterie" in "maklik hanteerbare" regsvorme wil laat oopgaan (vgl. bv. (ii)-(vi) hierbo). Hierdie geoogklapte regspositivisme spruit uit 'n - eweneens wesenlik regspositivistiese - tradisionalistiese regshistorisme voort (kyk weer eens bv. (i) en (iv) hierbo). 


\section{J. Du Plessis as Regsdenker.}

Ook dic eksponenete van die Engelsregtelike of, breër gestel, die Angel-Saksiese rigting in dic Suid-Afrikaanse reg en regswetenskap word deur Du Plessis hulle regspositivisme verwyt. Dit doen hy veral in sy artikel oor wetgewersoewereiniteit (Du Plessis 1960(f)), waarin hy G.Dietze (1959) se histories gefundeerde argumente met betrekking tot "judicial review" in dic VSA en in samehang daarmee die opkoms en werking van die "rule of law" ontleed. In die gemelde artikel is Du Plessis se uiters genuanseerde historiese bewussyn in hoogste versnelling. Daarom is die artikel - juis in sy verwikkeldheid - oorspronklik "ontradisioneel" en die skrywer se analises van heelwat gemeenplasige vooroordele bevry. Du Plessis se argumentasie kom, kernagtig saamgevat, op die volgende neer:

Dietze sien, taamlik ongekwalifiseerd, in 'n verskanste grondwet (of dan menseregte-akte in 'n grondwet) met 'n daarmee gepaardgaande toctsingsreg deur die howe - min of meer op die VSA-lees geskoei - die enigste werklike waarborg vir die beskerming van die individuele staatsburger se regte en vryhede. In ten minste sy ongekwalifiseerde en "ongenuanseerde" vorm bevraagteken Du Plessis - net soos W. H. B. Dean (vgl. Forsyth \& Schiller (reds.) 1979, p 74) bykans twintig jaar later - so 'n insig, hoofsaaklik omdat 'n legalistiese "vashou aan 'n geskrewe grondwet", op niks anders as 'n kontinuering en uitbouing van die regspositivisme sal neerkom nie. 'n Verskanste grondwet en die "rule of law" se kanse op welslae word verder verskraal indien die mite van parlementêre "omnipotence" bly voortleef, want 'n almagtige parlement sou selfs 'n polisicstaat kan sanksioneer, en die howe, wat dan hierdie optrede van die parlement sou mocs tocts, is steeds aan die oppermagtige parlement se wette (wat hierdic optrede sanksioneer) gebonde. Hier ontstaan dus 'n anamolie sonder dat dit - gelukkig - cgter "werk":

"Matthew Arnold het tereg gesê dat 'n Engelsman geen moeilikheid het met 'n anomalie nie, as dit maar werk," verklaar Du Plessis (1960(f), p 167) en vervolg dan: "En sy 'omnipotence of parliament' is 'n anomalie, maar dit werk, omdat dit nic werk nie, d.w.s. nie toegepas word nie".

Verskanste bepalings in 'n grondwet móét dus nie alleen - soos die positiviste sou meen - met dic maatstaf van of die geldende reg ò dic "meerderheidswil van die volk" : "die tirannic van dic helfte plus een" nocm Du Plessis (1960(f), p 168) dit - gemeet word nic maar met dic maatstaf van geregtigheid.

Tot sover lê Du Plessis die grondslae van en vir vernietigende (eensydige) regspositivistiese invloede in ons reg op 'n meesterlike wyse bloot. 'n Eksponent (of dan ten minste "leerling" in dic linie) van die Angel-Saksiese rigting in die Suid- 


\section{Lourens M. du Plessis}

Afrikaanse reg, John Dugard (1971 en 1978), het enkele jare later tot bykans soortgelyke gevolgtrekkings in verband met die invloed van die regspositivisme in die Suid-Afrikaanse regsteorie en -praktyk geraak. Dugard meen, net soos Du Plessis, dat hierdie invloed hoofsaaklik negatief was. Waar Dugard egter-redelik simplisities - 'n keuse vir 'n sogenaamde "natural law cum realist"-benadering as 'n heelmiddel teen regspositivistiese infeksies aandui, doen Du Plessis twee meer genuanseerde uitweë uit hierdie dilemma aan die hand

(a) In die eerste plek konstateer Du Plessis (1960(f), p 167) dat "die Engelse regsideologie ten diepste nie die regspositivisme van 'n absolute wetgewersoewereiniteit" tor grondslag het nie: “' 'n Engelsman kan dit nie sê nie, maar hy kan dit aanvoel". Eintlik behels die "rule of law" 'n erkenning van die feit dat die individuele mens "beelddraer van God en sowel nasie-mens as individu en nog veel meer" is, en word die "omnipotence of parliament" slegs geduld "so lank as die parlement of die heersende party 'plays the game', dit wil sê sy perke erken ..." (Du Plessis 1960(f), p 173). 'n Soortgelyke erkenning meen Du Plessis ook in ons Romeins-Hollandse (Christelike-Germaanse) regserfenis te bemerk. Die "natural law" - (qua regsideële) element in Dugard se benadering kan Du Plessis waarskynlik dus - net soos Dugard dit in 'n groot mate doen - as 'n historiese gegewene in en uit ons regstradisie beskou.

(b) Tweedens is Du Plessis (1960(f), p 172) nie 'n besliste teenstander van 'n verskanste akte van grondregte en 'n toetsingsreg deur die howe - as middele om "orde in vryheid, maar ook vryheid in orde" te verseker - nie, mits die invoering daarvan met ' $n$ "ideologie van eerbied vir die gegewe elemente van die reg soos in ons beskawing gefundeer in ons Christelike geloof en ons Westerse beskawing en nasionale tradisie, maar ook in ons internasionale aspirasies" gepaard gaan. Reeds in sy 1934-artikel oor staat en reg het Du Plessis (1934(b), p 144) myns insiens onherroeplik vir die regstaat contra die magstaat gekies, want hy skryf byvoorbeeld:

"Die regsvormende wilsuiting kan... nie willeke urig wees nie, maar moet tot op sekere hoogte georiënteer wees a an die regsbeginsels wat in sigself onafhanklik is van willekeur".

Die begrensing van absolute owerheidsgesag sien Du Plessis nooit los van 'n bcgrensing in terme van die beginsel van soewereiniteit in eie kring nie. Wetgewersoewereiniteit is daarom altyd slegs èn 'n afgeleide èn 'n tot die cie kring van 'n bcpaalde samelewingsinstelling beperkte soewereiniteit. Omdat die staat niks mecr 


\section{J. Du Plessis as Regsdenker}

as 'n soewerein in eie kring-samelewingsinstelling is nie, móét parlementêre soewereiniteit daarom ook slegs as 'n nie-absolute (deur die eie-aard van die staatlike kring begrensde) kompetensie tot regsvorming opgevat word (vgl. bv. Du Plessis 1960(f), p 171). Dit is jammer dat Du Plessis in gebreke gebly het om hierdie tese van hom ook met verwysing na die inticme korrelasic tussen die menseregte van individue sowel as "groepsformasies" aan die een kant en die regsorde aan die ander kant verder te verfyn (kyk in hierdie verband my Du Plessis 1979(a) en (b) ).

Die interpretasie van L. J. du Plessis se waardering van die "konkrete" Suid-Afrikaanse reg en regskultuur is ten slotte nie volledig indien daar nie van sy 1961 skrywe aan The Soutb African Law Journal (Du Plessis 1961(a)) kennis geneem word nie. Hy rig hom hierin tot die redakteurs van die blad, proff H.R. Hahlo en Ellison-Kahn, albei "verteenwoordigers" van die merendecls Engels georiënteerde tradisie van regsgeleerdheid in Suid-Afrika, en hy doen - "now that 1 am declining towards old age and senility and South Africa is being reborn into the Republic" - 'n beroep op alle juriste - "on and off the Bench" - "to open their minds to the 'winds of change' that now blow the world into a diversified unity on a broader front than dreamt of in the politics of Supermac" (Du Plessis 1961(a), p 457).

Wat behels sy pleidooi vir'n openheid teenoor dic gemelde winde van verandering? In die eerste plek betoog hy dat seksionele belange opsy geskuif en dat dic regbank, die regsprofesie, die regering en akademici aan dic totstandkoming van 'n inklusiewe Suid-Afrikanisme op regsgebied moet meewerk:

"Up to now we have been pestering one another with sectional and narrowminded, at any rate now antiquated, recriminations of antiquarianism on the one side and Anglo-Saxonism on the other . . . . . wish to appcal for a new South Africanism in the law of the Republic" (Du Plessis 1961(a), p 457).

Die konsolidasie van die gemene (Romeins-Hollandse) reg tot 'n eie Suid-Afri- kaanse reg - dĭt met tegelyk 'n oopstelling vir bevrugtende inwerking van invloede uit die Europees-Kontinentale reg - is 'n besliste prioritcit.

Tweedens is 'n kennis van die Kommunistiese en die Oostersc reg ook 'n noodsaak:

"... (F) or these can only be conquered by being understood, and be neutralized by having their thunder stolen" (Du Plessis 1961(a), p 458). 


\section{Lourens $M$. du Plessis}

In die derde plek moet die inheemse reg van die Swartmense gemoderniseer en weifelloos by die Suid-A frikaanse reg geintegreer word.

Ten slotte moet ' $n$ "really South African legal theory ... based on our own national, nay multi-national, Western and yet African ethos" met verwysing na - en tegelyk in verdere voortbouing op - bestaande regsteorieë, soos dié van Austin, Dicey, Kelsen, Pound, Dooyeweerd, Friedmann en Stone, ontwikkel word (Du Plessis 1961(a), p 458).

En dan stel hy - byna vreesloos - sy voorstelle aan kritiek bloot:

„Let the test be the emotional reactions in our legal fraternity to this effusion of mine. These are immaterial to me, but it may be interesting to watch if there were a means of scanning the motions of the mind and the heart . . " (Du Plessis $1961(\mathrm{a}), \mathrm{p} 458$ ).

Inderdaad, die groot, soekende gees van L. J. du Plessis het hom nie deur die sjibbolette van konvensionalisme laat inhok nie; daarom kon hy by die kleinlikhede van sy tyd verbykyk en dié regsorde waarvan ons vandag, twintig jaar later, met meer realisme droom, in klaarheid voor sy deurpriemende geestesoog aanskou!

\subsection{J. du Plessis en Dooyeweerd}

L J. du Plessis was ongetwyfeld 'n aanhanger van Dooyeweerd en sy filosofie maar beslis geen epigoon nie: daarvoor is hy gans te veel van ' $n$ individualis. Gevolglik bedien hy hom veelal van die regsfilosofiese insigte van Dooyeweerd, meesal as ' $n$ hulpmiddel om die probleme waaroor hy skryf, teoreties prinsipieel in perspektief te plaas.

Potgieter (1972, p 40-6) sê nogal heelwat omtrent dic wyse waarop Du Plessis by Dooyeweerd a ansluiting vind. Ek meen dat Potgieter se interpretasie - soos ook uit hierdie artikel sal blyk - korrek is. In 'n neutedop gestel kom dit daarop neer dat Du Plessis nie soseer (in die eerste plek) 'n kritiese nie maar wel 'n oorspronklike aanhanger van Dooyeweerd was - iemand wat aan die Wysbegeerte van die Wetsidee ' $n$ eie nuanse kon en wou gee en derhalwe tot die uitbouing daarvan kon bydrae. Die Nieu-Calvinistiese filosofie uit Amsterdam moes eenvoudig iets vir die eie probleme van Suid-Afrika te sê hê (vgl. bv. Du Plessis 1957(b)). Daarom gaan Du Plessis in sommige opsigte verder as Dooyeweerd. Dit is ook opmerklik dat hy veral teen die einde van sy loopbaan al hoe meer probleme 


\section{J. Du Plessis as Regadenker}

met die Wysbegeerte van die Wetsidee ondervind het (vgl. bv. Du Plessis 1958(a) en 1962, p 309-19 asook die anhangsel tot hierdie artikel). Hierdie meer kritiese instelling korreleer ongetwy feld met die verbreding van sy eie histories gefundeerde insigte met 'n sosiaal-eskatologiese visie op 'n werklikheid-in-ontplooing (kyk ook 5.3 hieronder).

Dit is opmerklik dat Du Plessis - sy dit ten goede of ten kwade - sekere kernbegrippe en -onderskeidings wat Dooyeweerd self tref, verontagsaam. So bevoorbeeld aanvaar hy Dooyeweerd se uitgangspunt oor die bestaan van bo-willekeurige, voor-positiewe regsbeginsels sonder om hom ooit oor Dooyeweerd se indeling van hierdie regsbeginsels te verantwoord (kyk bv. Du Plessis 1978, p 532-9, en Hommes 1969). Is dit miskien omdat hy nie met Dooyeweerd se kernonderskeid tussen dinamiese en konstante regsbeginsels vrede kon vind nie? In ieder geval wil dit voorkom asof alle regsbeginsels vir Du Plessis altyd 'n dinamiese kant het (kyk 5.1 hieronder).

Voorts onderskej Du Plessis nêrens juis tussen dit wat Dooyeweerd regsbeginsels en dit wat hy grondbegrippe van die regswetenskap noem nie - hy identifiseer hulle tewens. Dit is ook opvallend dat die Dooyeweerdiaanse onderskeid tussen die elementêre en die kategoriale of samegestelde grondbegrippe van die regswetenskap (vgl. Dooyeweerd Encyclopaedie (b), p 11-28 en 98-102; Hommes 1972 en 1976 en Du Plessis 1978, p 509-19) Du Plessis se aandag heeltemal ontglip.

\subsection{J. Du Plessis se invloed op regsgebied}

Ek kan nie anders as om met groot waardering oor die werk van 'n groot voorganger op regsfilosofiese gebied aan die PU vir CHO (en in Suid-Afrika) te skryf nie. Dit maak my meteen subjektief betrokke by die lewe en werk van L. J. du Plessis, en daarom is die gevaar dat ek sy de facto-invloed op regsgebied té hoog kan aanskryf, nie onwerklik nie. Selfs al sou ek egter sy de facto-invloed oorskat, meen ek nog steeds dat die intellektuele spankrag, die ruimheid van visie en die skerpheid van insig wat sy arbeid op regsgebied èn gedra èn gekenmerk het, nouliks oorskat kan word. Al het baie van sy studente en kollegas hom dikwels misverstaan, verwys hulle almal nog steeds met groot waardering na die briljante "prof .Wikus", en dan nie alleen na sy dikwels skreeusnaakse pittighede, anekdotes en eg individualistiese "vagaries" nie maar ook na sy heldere en rigtinggewende insigte. Niemand wat Wikus du Plessis geken het, het lou gevoelens oor hom nie. En dít getuig inderdaad van sy invloed op die mense om hom - van die vermoëns van 'n meester wat "dinge kon laat gebeur". Die volle waarheid is miskien dat 


\section{Lourens M. du Plessis}

L. J. du Plessis se de facto-invloed buite verhouding klein is tot sy werklike invloedspotensiaal - 'n potensiaal wat tot op hede nog nie behoorlik ontgin is nie en sekerlik deur 'n indringende bestudering van sy regsgeskrifte - ook ter wille van die Suid-Afrika en Suid-Afrikaanse reg wat hy so uitnemend liefgehad het "in aksie gestel" sal kan word. Het dit nie miskien tyd geword om L. J. du Plessis se geskrifte as ' $t$ ware aan die vergetelheid te ontruk en in 'n publikasie saam te bundel nie?

Kontroleerbaarder en verifieerbaarder is L. J. du Plessis se invloed op sekere van sy bekende leerlinge en kollegas - die meeste van hulle tans prominente akademici. En hier dink 'n mens in die eerste plek onwillekeurig aan sy leerling en kollega, J. D. van der Vyver, voorheen hoogleraar in Regsfilosofie aan die PU vir CHO en tans van die Universiteit van die Witwatersrand. Saam met F. J. van Zyl, 'n jonger kollega van Du Plessis, het Van der Vyver 'n werk onder die titel Inleiding tot die regswetenskap (Van der Vyver \& Van Zyl 1972) die lig laat sien. In hierdie werk is baie van die insigte van L. J. du Plessis benut en met die oog op die bevattingsvermoë van eersteja arstudente vereenvoudig. Die outeurs steun ook natuurlik op die insigte van Dooyeweerd, maar dan dikwels 'n Dooyeweerd soos verwerk en aan hulle bekendgestel deur L. J. du Plessis (vgl. veral hoofstuk 5,6 en 10).

Daarbenewens het Van der Vyver 'n terrein wat L. J. du Plessis grootliks onaangeroerd gelaat het, verder gaan verken. Ek verwys hier natuurlik na Van der Vyver (vgl. bv. 1973, 1975 en 1976) se bekende en indringende navorsing oor die probleem van menseregte, waarmee hy vir homself'n onbetwiste (besondere) staanplek in die geledere van die Suid-Afrikaanse juristekorps uitgekerf het. Ongelukkig ontbreek die ruimte om aan te toon presies hoe groot Du Plessis se invloed op Van der Vyver was.

Onder Du Plessis se bekwame leiding het ook J. Raubenheimer (1961) 'n proefskrif voltooi wat oor die moontlike instelling van administratiewe howe in SuidAfrika handel - 'n onderwerp wat tans nog druk bespreek word.

Du Plessis het baie van sy kollegas met die regsfilosofic van Dooyewcerd laat kennis maak - met insig laat kennis maak. Afgesien van F. J. van Zyl dink 'n mens ook aan akademici soos H. L. Swane poel en W. A. Joubert (vgl. Bv. Joubert 1958). Selfs iemand soos A. D. J. van Rensburg, een van Joubert se leerlinge, hanteer die Wysbegeerte van die Wetsidee ofskoon dan nie met 'n kritiekloos instemmende nie dan tog wel steeds met 'n waarderende 


\section{J. Du Plessis as Regzdenker}

nougesetheid in sy proefskrif oor juridiese kousaliteit (Van Rensburg 1970, p 105-53). Is dit vergesog om daarin 'n middellike nawerking van $L$. J. du Plessis se invloed te bespeur?

Ten slotte moet die een en ander oor Du Plessis se besondere verhouding tot sy vriend, H G Stoker - 'n ander groot Pot chefstromer "op die voorpunt van die tye" - opgemerk word. Afgesien van die feit dat Du Plessis deurentyd sy gedagtes in gesprek met Stoker ontwikkel en ook heelwat van Stoker se insigte sy eie maak (vgl. bv. Du Plessis 1957(a)), gee hy ook Stoker aan as sy promotor met die oog op sy proefskrifpogings (Du Plessis 1961(e) en 1962). In 'n brief aan Stoker verwoord Du Plessis (1960(b) ) self èn die verhouding tussen hulle in sy waardering vir Stoker onder andere só:

"Nieteenstaande dat ek deurgaans op sekere punte radikaal van jou verskil het en nog verskil, het ek tog in jou steeds gewaardeer

(1) dat jy 'n denker is en nie maar net 'n naprater soos feitlik al ons plaaslike geestelik leidsliede nie; en

(2) dat jy daarom nooit alle antwoorde op alle vrae persklaar het nie.

Ek self het nog lank nie klaar ontwikkel nie - hetsy opwaarts of neerwaarts; maar ek wil to teen volgende jaar op my werkgebied voorlopig my gedagte-ontwikkeling tot dusver saamvat.

En met die oog daarop wil ek graag op jou dinkwerk, wat blykbaar nou reeds 'n betreklike vastigheid bereik het, so ver moontlik voortbou, aangesien jy alleen so ver ek weet 'n verdere ontwikkeling toon van die Calvinistiese denke sedert Dooyeweerd".

Dit is jammer dat - die Christelik-Reformatoriese tradisie in ons sand ten goede die in hierdie skrywe geantisipeerde samewerking tussen Du Plessis en Stoker nooit volle wasdom kon bereik nie. Tog is dit sekerlik nie vergesog om te vermoed dat L. J. du Plessis ook op en via Stoker heelwat invloed uitgeoefen het nie. Is Stoker (1970(a) ) se belangstelling in die reg en regskwessies - en dǐt op 'n betreklik gevorderde leeftyd - nie mar een stille getuienis van 'n intieme band tussen hom en Du Plessis nie? 


\section{Lourens M. du Plessis}

\section{DIE GRONDSLAE VAN L. J. DU PLESSIS SE REGSDENKE}

\subsection{Sy algmeen Calvinistiese benadering.}

Tot dusver is L. J. du Plessis se arbeid op regsgebied en sekere van sy opvattings met betrekking tot die Suid-Afrikaanse reg in perspektief geplaas. Ek wil vervolgens op die regsteoretiese uitgangspunte waarop Du Plessis hom stel, ingaan en daarmee 'n greep op sy bydrae as reformatoriese regsdenker probeer kry. Dit kan ongelukkig uiteraard slegs kursories gedoen word, en daarom gaan ek besondere klem op die onderskeidende of unieke kenmerke in sy regsfilosofie laat val.

Du Plessis was 'n Calvinis - 'n wat ek sou wil noem outentieke Calvinis. In Suid-Afrika vaar heelwat lewensbeskouinge onder die vlag van "Calvinisme". Meer as dikwels word wesenlik nie-Calvinistiese lewensbeskouings en ideologieë, soos kapitalisme, Afrikanerchauvinisme of -rassisme en selfs 'n verskeidenheid vorme van puriteins konswerwatistiese tradisionalisme (soos die "dopperisme" waarna Du Plessis meermale verwys), utopistiese absolutisme en mensverheerlikende liberalisme met 'n Calvinisitese sousie gekamoefleer. In hierdie gevalle is die sogenaamde Calvinisme 'n middel tot 'n wesenlik nie-Calvinistiese doel 'n instrumentele Calvinisme wat, in 'n samelewing waar die blote naam "Calvinisme" nog gewig dra, aan 'n verskeidenheid prinsipieel humanistiese ideologieë geloofwaardigheid moet verleen. Die outentieke Calvinisme stel homself egter histories bewus op een lyn met daardie stroming in die Christendom wat in die sestiende eeu - veral rondom en onder invloed van die reformatoriese arbeid van mense soos Calvyn - 'n opvallende bloeityd beleef het. Die kenmerk van hierdie stroming is dat dit "gesaghebbende" waarheid met God se openbaring (in die Skrif, die "oorspronklike" skepping en die geskiedenis) vereenselwig. Die Bybel as "Boek van die geloof" is sy sentrale gesagsbron. Sola gratia, sola Scriptura en soli Deo gloria is sy leuse. Besondere gewig word verleen aan die feit dat rod sy kinders deur die geloof regverdig verklaar, en hierdie heilsfeit (so word geglo ) het implikasies oor die ganse linie van menswees. L. J. du Plessis is 'n Calvinis met 'n eie styl en 'n eie aanslag wat, gegee sy historiese sensitiwiteit, veral na die juridies-staatk undige implikasies van God se openbaring in Skrif, skepping en historie probeer deurtas.

Potgieter (1972,p. 25-51) gee 'n goeie opsomming van die Calvinistiese uitgangspunte wat L. J. du Plessis aanvaar. Ek gaan dit hier nie herhaal nie, maar ek sal telkens in die loop van die verdere bespreking - waar ter sake - daarna terugver wys. 


\section{J. Du Plessis as Regadenker}

\subsection{Christelike (regs-) wetenskap}

L. J. du Plessis was 'n uitgesproke voorstander van die beoefening van 'n Christelike regswetenskap:

"Dat die wetenskap van die reg uit Christelike beginsel benader moet word, is van . . belang omdat die reg nie alleen gedurig verander en ontwikkel nie, maár omdat daardie ontwikkeling langs normaticwe weg plaasvind. . so dat dit gevorm word volgens 'n reël of ideaal" (Du Plessis 1943(a), p. 172-3).

Die "Christelike beginsel" moet eensdeels help om die interpretasie van die materiële (regs-)beginsels wat- voor-positief en bo-willekeurig - aan alle positiewe reg ten grondslag lê, aan "die Heilige Skrif en . . Calvinistiese uitleg en toepassing" te oriënteer en andersdeels as regspolities ideële regsorde dien - dit alles in die lig van die besondere eise en behoeftes van die tyd. Grondige, prinsipiële (na-) denke in die regslewe moet "bare advokatery" vervang (Du Plesis 1943(a) p. 173-4).

Oor die dát van 'n Christelike regswetenskapsbeoffening - net soos oor die kultuurhistoeriese gegewens en probleme waarop die Christelike regswetenskap toegespits moet wees - bestaan daar by Du Plessis wienig onduidelikhied. Van die bóé van 'n Christelike regswetenskap - die sistematies besinnende wyse waarop en/of metode waarvolgens " die heilige Skrif en ... die Calvinistiese Skrifuitleg en toepassing" met regswetenskapsbeoefening geintegreer kan word kan ongelukkig nie dieselfde gesê word nie. Die wete dát figureer meesal slegs as 'n intuitiewe onderbou by die in-die rpraktyk-stelling van die boe. Du Plessis se "bouplan" vir 'n Christelike regswetenskapbeoefening het dus nooit tot 'n afgeronde geheelbeeld ontplooi nie en moet gevolglik merendeels ex post facto (interpretatief) blootgelê word.

Hierdie gebrek verduidelik Du Plessis (1960(b), p. 2) soos volg aan Stoker:

“Ek wens soms dat ek ook so skematies en volledig kategories of kategoriaal kon dink soos jy, maar die konkrete en die toekomstige dwing my te seer om daarby lank te kan verwyl; trouens dit oortref seker my vermoë en verwek gevolglik gemelikheid en ongeduld".

\subsection{Die reg as sodanig}

Die volledigste sistematiese uiteensetting van die grondslag van Du Plessis se regsbeskouing gee hy in sy 1943-inleiding tot die algemene regsleer (Du Plessis 


\section{Lourens M. du Plessis}

1943 (b), p. 322) en in sy regsleerdiktate (Du Plessis 1956/57, p. A1-23). Ek dink dat Potgieter (1972, p. 97) gelyk het wanneer hy beweer dat Du Plessis in die laasgenoemae geskrif merendeels/daarop uit is om Dooyeweerd se regsteiorie op 'n svereenvoudige wyse: aan sy studente te verduidelik. Die 1943-werk het beslis meer van 'n eie styl en aanslag, en daarom verwys ek hoofsaaklik daarna. Puntsgewys opgesom kom Du Plessis se regsbeskouing op die volgende neer:

(i) Die reg - na sowel vorm asinboud (of materie) - bestaan werklik, en wel as 'n eiesoortige aspek van die volle werklikbeid (as skepping van God) wat "beleef, beoefen en ook erken en bestudeer" kan word (Du Plessis 1943 (b), p. 4-5, en 1956/57, p A1).

(ii) Die reg is "'n normatiewe verskynsel. . .wat 'n beroep doen op menslike oordeel en wil" (Du Plessis 1943(b), p5). In sy normatiwiteit (of wetmatigheid) is die reg te onderskei van sowel natuurwetmatigheid as etiese en sosiale (in die sin van fatsoenlikheids-) normkomplekse (Du Plessis 1943(b), p6; 1956/57, pA2-3).

(iii) As vergeldingsgegewene (hieroor in 5.1 hieronder meer) geld die reg as gedragsreëling in sowel staatlike as nie-staatlike samelewingskringe (Du Plessis 1943(b), p6; 1956/57, pA2-3).

(iv) Alle positiewe reg berus (na die inhoud daarvan) op (voor-positiewe bo-willekeurige regsbeginsels en (na die vorm daarvan) op die bistoriese gefundeerde positiveringsakte van 'n kompetente regsvormer (Du Plessis 1943(b), p. 7). Die positiveringsakte van 'n wetgewer word weer deur òf ooreenkoms ò bevel gerugsteun, albei waarvan èn histories gefundeer is èn uitdruklik of stilswyend kan weès (Du Plessis 1943(b), p.16-7). Ooreenkoms en bevel is dus ontstaansbronne van die reg, dit wil sê "die regsvorme waarin regsbeginsels gepositiveer word tot geldende reg" (Du Plessis 1943(b), p 16) of, in die taal van Van der Vyver en Van Zyl (1972, p 85) uitgedruk, die geldinggewende gegewenes wat aan enige "medium waardeur reg gepositiveer word" (soos wetgewing, gewoonte en presedent) ten grondslag lê. Oor die kwessie van regsbeginsels word in 5.1 hieronder meer gesê.

(v) Regsnorme verbind gevolge aan èn handelinge waardeur hulle geëer biedig èn handelinge waardeur hulle geskend word (Du Plessis 1943(b), p.7-8).

(vi) Die regsorde as normsisteem - "waarvan die dele met mekaar verbind is tot 'n oorsigtelike eenbeid" - neig voortdurend om "tot groter algemeenbeid van strekking en tot gelykbeid van behandeling.... asook tot 


\section{J. Du Plessis as Regsdenker.}

groter regsekerheid" te ontwikkel. Regsnorme geld voorts binne 'n bepaalde gebied en vir 'n bepaalde tyd (Du Plessis 1943(b), p.8).

Die reg as regsorde (dit wil sê "objektiewe" reg of wetstelsel) definieer Du Plessis (1943 (b), p.8) op die voetspoor van Dooyeweerd as:

“. . dié sisteem van norme.... . wat uit Godgestelde beginsels gepositiveer is deur die wil van bevoegde vormingsorgane in die verskillende sameleweingskringe in onderlinge korrelasie, met bepaalde geldingsgebied en geldingstyd, waardeur langs die weg van afbakening, toela ting en magtiging, gebod en verbod, ens., 'n vereffening van belange in die samelewing verseker word deurdat bepaalde vergeldingsgevolge verbind word aan bepaalde vergeldingsgronde, en dit wel met die groots moontlike mate van algmeenheid en sekerheid".

Du Plessis definieer eintlik die - wat Dooyeweerd (Encyclopaedie(a)II, p123-4) sal noem - regsbegrip na die wetsy van die juridiese aspek (met die subjeksy, wat Dooyeweerd wel in sy definisie van die regsbegrip insluit, uitgesluit). Dit is myns insiens 'n gebrek by Du Plessis dat hy die normatiewe (of Norm-) aspek van die regsorde oorbeklemtoon - te meer in die lig van sy latere kritiek op Dooyeweerd dat laasgenoemde tè veel "van 'n wetsgrondslag vir die kosmiese werklikheid uitgaan" (Du Plessis

1962, p310). Dit is egter veeiseggend dat Du Plessis hierdie kritiek kwalifiseer deur te sê dat Dooyeweerd se wetsbenadering met betrekking tot sy regsbeskouing wel uiters vrugbaar was - 'n aanduiding van die feit dat Du Plessis selfs in sy "laaste geskrif" sy redelik eksklusief normatiewe blik op die regsorde behou.

Ter versagting moet gesê word dat Du Plessis (vgl. 1943(b), p. 10-5; $1956 / 57$, p. A3-5) nie die subjekte of "onderdane" van regsnorme (en begevolg die regsorde) uit die oog verloor nie. Die subjekte van die reg is volgens hom persone (natuurlike sowel as regspersone), regsfeite, regsobjekte en subjektiewe regte. Die reg in subjektiewe sin - synde 'n sisteem van regsverhoudinge - is egter nie by die regsorde as sodanig geintegreer nie maar is hoogstens daaraan onderworpe. Stoker (1970a, p. 9 en 49-50) se omskrywing van die regsorde as "die geheel van menseregte en regsnorme met hul onderlinge verhoudings" bevredig in sy ruimheid na my mening mèèr as diè van Du Plessis. Uit die feit dat Du Plessis normatiewe ordelikheid en regsubjektiwiteit of "-onderdanigheid" aldus uit mekaar uit haal, moet myns insiens sy onbevredigende hantering van menseregtekwessies - iets waarna (in 2.2 ) hierbo reeds verwys is - verstaan word. 
Lourens M. du Plessis

Voorts wil dit voorkom asof Du Plessis, omdat - soos voorheen (2.3 hierbo) reeds aangetoon - hy teoreties sistematies gesproke die kategoriale of "samegestelde" geheeldimensionele perspektief op die 1 eg en regsbegrippe (aliter grondbegrippe van die regswetenskap) mis, anders as die "latere" Dooyeweerd (Encyclopaedie (b)II, p.264) nooit ingesien het dat die reg (en regsnorme) eintlik nie definieerbaar is nie. Du Plessis se visie op die ireg(-sorde) inoet, in terme van Dooyeweerd se latere insigte, as 'n bloot elementêre ("horisontalistiese") visie beskou word 'n visie wat die kategoriale (of samegestelde of "vertikale" dimensies (qua relasies) van regsnorm-regsfeit, subjek-objek en ontstaan en totnictgaan (ook in hulle onderlinge samehang en/of korrelasie) mis. Volgens Dooyeweerd (Encyclopaedie (b) II, p. 10) is die regsbegrip self die gekompliseerste kategoriale grondbegrip van die regswetenskap en juis in sy kompleksiteit ondefinieerbaar!

\subsection{Reg(-swetenskap) en werklikheid}

Tipies van sy konkrete ervaring op wetenskaplike gebied kan L.J. du Plessis nie met 'n blote in abstracto cendimensioneel begripsmatige - analise van die reg volstaan nie. Insigte wat hy in sy sistematies teoretiese miskyk van die kategoriale dieptedimensie van die reg en regsorde ontbeer, kom de facto in sy bespreking van die verwerkliking van die reg wel na vore.

Die reg word op hoofsaaklik vier wyses "uit sy beginsels tot sosiale gelding en werking gebring" - vier wyses wat ook opeenvolgende stappe in 'n ingewikkelde proses" verteenwoordig (Du Plessis 1943 (b), p 16-22):

(i) Deur positivering, "dit wil sê die gesaghebbende uitwerking van regsbeginsels tot geldende neergelegde (positae) regsnorme" - dit op sterkte van uitdruklike of stilswyende bevel en ooreenkoms. Bevel bring regsnorme tot stand in gevalle waar die regsvormer as "hoof" in 'n regskring norme vir sy "ondergeskiktes" neerlê. In die geval van ooreenkoms is die lede van die regskring gelyk, dit wil sê newegeskik tot mekaar. Die totstandkoming van gewoontereg berus op stilswyende ooreenkoms (Du Plessis 1943 (b), p 16).

(i i) Deur regsinterpretasie of -vertolking of, liewer, die interpretasie of vertolking van "die tekcns" (of taal) "waardeur die reg aangedui word". Interpretasie beteken vir Du Plessis (1943(b), p 17) méér as dat bloot by wyse van logiese deduksie uit 'n algemene regsnorm 'n toepassing vir 'n konkrete geval afgelei moet word. Regsnorme het immers betekenis in ' $n$ historiese gegewe konteks, wat die bestaan van 'n eiesoortige (hier en nou gegewe) konkrete situasie veron- 


\section{J. Du Plessis as Regsdenker}

derstel. Interpretasie van die reg behels bygevolg die "eksistensialisering" van "begripsgekonsipieerde" norme in 'n konkrete (historiese) situasie. Du Plessis se sensitiewe (historiese) werklikheidsbewussyn (kyk ook 5.1 en 5.3 hieronder) help hom om die voetangels van 'n (louter abstrakte) Begriffsjurisprudenz te vermy.

(iii) Deur toepassing van die reg op die besondere geval - soos reeds in ( $\mathrm{i} i$ ) hierbo geimpliseer (du Plessis 1943(b), p 17-8).

(iv) Deur die uitvoering van die gepositiveerde, vertolkte en toegepaste reg (Du Plessis 1943(b), p 18 e v ).

\subsection{Reg en regsidee (aliter geregtigheid;}

Tot dusver is die reg bloot in terıne van sy gekonstitueerdheid en verwerkliking as sodanig betrag. Die regsidee"reguleer" egter ook die reg - stuur dit in 'n bepaalde rigting - met die oog op die verwerkliking van (die idee/ideë van) reguerdigheid en billikheid. Hieroor in 5.1 hieronder meer.

\subsection{Reg en st2at}

Die staatstaak is volgens Du Plessis (1934(a), 1941(a), p 68-74, en 1956/57,p A12-3) primêr 'n regstaak. Op die volledige besonderhede hiervan kan ongelukkig nie té ekstensief ingegaan word nie (vgl. vir 'n goeie uiteensetting Potgieter 1972, p. 101-14). Daarom slegs enkele hooftrekke.

Die staat (of staatsowerheid) is regsvormer en -handhawer par excellence. Staatlike soewereiniteit is bygevolg volgens Du Plessis (vgl. bv. 1959 (b) 1960 (f) altyd 'n juridies gekwalifiseerde soewereinitiet - "'n eienskap van 'n bepaalde regsbevoegdheid" en bygevolg "'n reg tot seggenskap oor onderdane" (Du Plessis 1941(a), p 71 - my kursivering). Staatlike soewereiniteit as eienskap van die staat se "bepaalde regsbevoegdheid" is egter niks meer as 'n soewereiniteit in eie kring nie. Ander samelewingskringe beskik dus ook oor soewereiniteit in eie kring - oor 'n "bepaalde regsbevoegdheid" met verwysing na ' $n$ (elkeen sy eie) taak en terrein. Wat is dan die eie, juridies gekwalifiseerde "kring" van die staat? Hoofsaaklik, so verduidelik Du Plessis (1934(b), p.146, en 1959(b), p. 9), die terrein van die (ius commene, dit wil sê die juridies ordenbare (inter-) terrein "tussen" die verskillende ander in eie kring soewereine samelewingsinstellings, elk met 'n eie interne, (intra-) terrein van en vir regsordening. Op regsgebied is die staat dus 'n "opperverband wat sy eintlike 


\section{Lourens M. du Plessis}

funksie vind in die juridiese ordening van die samelewing tussen verskillende verbande en hulle lede" (Du Plessis 1934 (b), p. 146). Gaan bemoei die staat hom met die interne regsake van 'n samelewingskring, steek hy op 'n totalitêre wyse die grense van sy eie terrein oor. Potgieter (1972, P 88) vat dit só saam:

"In die beperktbeid van die owerbeidsgesag is die vrybeid van die ander gewaarborg, want enige magsaanwending van die owerheid moet gegrond wees in laasgenoemde se regshandhawende funksie en nie in willekeurige staatsmag nie".

Kortom, die gehoorsaming en toepassing van die beginsel van soewereiniteit in eie kring waarborg prinsipeel gesproke die bestaan van 'n konstitusioncle regstaat (vgl. bv. Du Plessis 1934 (b), p.141). Gevolglik is dit eweneens dic beginsel van soewereiniteit in eie kring wat die bestaan van 'n verskeidenheid regsordes en -soorte moontlik maak. In breë trekke onderskei Du Plessis tussen reg in die staatlike kring (staatlike reg) en (interne) reg in nie-staatlike kringe (nie-staatlike reg). Waar daar 'n geordende samelcwingskring bestaan, daar bestaan tegelyk 'n reële, eiesoortige reg (regsorde) wat die interne sake van die samelewingskring vergeldend reël. Du Plessis (1956(b), p. 101-2) beskou byvoorbeeld die Dordtistiese kerkregopvatting wat die kerkreg nie as (interne verbands-) reg wil beskou en die kerkorde daarom ook nie as 'n regstelsel nie, as 'n "skadelike repristinasie in ons regsopvatting op die gebied van (die)kerk".

Deur staatlike en nie-staatlike reg tegelykertyd èn as werklik(e) rég te beskou èn van mekaar te onderskei, huldig Du Plessis geen oorspronklike - in die sin van 'n "nuwe" - standpunt nie. Met die oog op bepaalde ontwikkelinge van (-uit) die primitiewe verbandsreg oor die middeleeuse gildereg heen en tor en met die moderne regspersonereg, wat weer om verskeie redes toenemend die invloed van staatkundige magskonsolidasie en - integrasie behoef, onderskei Du Plessis (1943(b), p. 19, 83-97 - en hierin is hy wel oorspronklik - 'n derde soort "grensreg" tussen staatlike en nie-staatlike reg, naamlik korporatiewe reg, 'n regsoort wat 'n heel konkrete beliggaming is $\mathbf{v}$ die feit dat die staat "teenswoordig ... in 'n groot mate deur ... regsvorming die werking van sosiale groepe normeer". Ongelukkig kan die finesses van Du Plessis se beskouing oor die korporatiewe reg hier nie volledig behandel word nie.

\subsection{Die distink tiewe en/of unieke in Du Plessis se regsdenke}

Die opmerksame leser sou in die uiteensetting van die grondslae van Du Plessis se regsdenke tot dusver baie van die grondgedagtes van Dooyeweerd terug- 


\section{J. Du Plessis as Regsdenker}

vind. Ewe markant behoort egter ook die eie aanslag en nuanse waarmee Du; Plessis hierdie grondgedagtes hanteer, te blyk. En tog val daar ook, n, eie, diss, tinktiewe of unieke benadering in Du Plessis se regsdenke te onderken in ben! nadering wat vanuit sy histories gefundeerde sosiaaleskatologiese visie op die werklikheid (en ook die werklikheid van die reg) verklaar kan wort, hierdie element van "eienheid" is in al sy regsgeskrifte oor 'n lang tydperk to be speur maar word veral sedert ongeveer 1956 opsetlik sistematies by sy,werk-, likheidsvisie betrek. Ek wil daarom sy kritiek op Dooyeweerd se fillosofie en regsfilosofie as 'n aanknopingspunt by die bespreking van die unieke in , sy, eie benadering gebruik.

\section{L. J. DU PLESSIS SE KRITIEK OP DOOYEWEERD}

Sisl IUSA :

leisinge

St:

Veral teen die einde van sy akademiese loopbaan het Du Plessis 'n groot voorliefde geopenbaar vir die gebruik om "wetenswaardige" geskrifte van andere as bylaes of anhangsels tot sy eie werke toe te voeg. So byvoorbeeld wou: hy A. Kuyper se Stone-lesings asook 'n hele aantal geskrifte van Dooyeweerd as bylaes tot sy 1962-proefskrif toevoeg. Veral omdat sy kritiek op Dooyeweerd - buiten twee nog nie volledig afgeronde artikels (Du Plessis 1957-(a)) en 1958 (a) - grotendeels onbekend is, voeg ek, so reg in die L. J: du Plessistradisie, die verbatim-weergawe daarvan in sy proefskrif (Du Plessis 1962, p. 309 -19) ('n weergawe wat terloops, nog in sy eie handskrif verskyn) as anhangsel (kyk hieronder) tot hierdie artikel toe. Sy kritiek qua kritiek is hieriti volledig uitgewerk. Ongelukkig - en dit is jammer - is sy kritiek ook nog ontribl: ledig in die sin dat die eie standpunt wat hy met verwysing na sỳ kintiese op merkings moes formuleer, òf nooir geformuleer is nie òf so nie op škkrif' gestèl is nie. Vir die huidige gee ek slegs puntsgewys 'n opsomming van die hoofmomente van sy kritick (met 'n voorlopige evaluering hier en daar) en bou' ek dan in 5 hieronder veral op punte (ii)- (v) voort.

(i) Dooyeweerd se Calvinistiese regsteorie onderhou geen regstreekse vethand met'n besondere teologie (teologiese standpunt) nie. Hierdie beswasr is myns insiens meer formeel as wat dit (materieel) wenslik van aard is, en ek laat dit gevolglik daar.

$$
\text { iis zratsudz }
$$

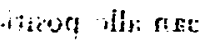

(ii) Dooyeweerd se "wetsbenadering" kan formalistiese (of oormatig formaliserende) gevolge hê;

ogys: hovis! (i) is!ising

(iii) Dooyeweerd se hantering van sowel die historiese (insluitend die fol van nasionaliteite) as

isi no \% \% 


\section{Lourens M. du Plessis}

(iv) die sosiale is onbevredigend. (ii), (iii) en (iv) moet in verband met mekaar gesien word, want Du Plessis rig hom veral teen Dooyeweerd se enigsins formalistiese (modaa! gebonde) hantering van die historiese en die sosiale.

(v) Dooyeweerd se hoofsaaklik modale benadering werk eensydigheid in die hand en lei tot 'n onbevredigende hantering van vergelding as wesenskenmerk van die reg. Dooyeweerd betrek vergelding nie eksplisiet op die gegewenheid van ('n) "ordelikheid" as sodanig nie - hy sê met ander woorde slegs boe die reg orden maar nie ook wat dit orden nie.

\section{NADERE ONDERSOEK V AN DIE DISTINKTIEWE IN L. J. DU PLESSIS SE REGSDENKE, MEDE MET VERWYSING NA SY KRITIEK OP DOOYE- WEERD.}

\subsection{Die historiese by L. J. du Plessis}

In sy brief aan Stoker maak Du Plessis (1969 (a), p. 1) - nadat hy sy waardering vir Stoker se werk betuig het - onder andere die volgende kritiese opmerking:

“Maar ook by jou voel ek nog te veel van 'n statiese element aan wat nie korrespondeer met die historiese bestaanswyse van die kosmos nie. Ek wil wel aanneem dat God alle potensies aan die begin in die skepping ingelê het, maar ek kan nie aanneem dat die aktualiteit van enigeen daarvan op enige historiese punt in die tyd volledig afgerond of uitgedifferensieer, hetsy ontologies of gnoseologies, geopenbaar is voor die voleinding nie."

Met hierdie enkele pennestrepe het Du Plessis die ontologiese basis van sy geskiedbeskouing blootgelê. En sy opvatting oor die aktualisering van "skeppingspotensies" in die loop van die geskiedenis - 'n metafisies-Aristoteliese segswyse wat hy met ' $n$ dinamiese inhoud vul - het implikasies vir sy regsbeskouing - veral vir sy siening oor die aard van regsbeginsels. Regsbeginsels lê aan alle positiewe regsnorme - wat in korrelasie met "die wisselende en ontwikkelende vereistes van die veelvoudige menslike samelewingskringe" (voortdurend) gepositiveer word - as bo-willekeurige, voor-positiewe momente ten grondslag (Du Plessis 1943(b), p. 6). Regsbeginsels self is op hulle beurt weer die "elemente" van gepositiveerde regsreëlings wat "in die natuur van die saak" gegee en wat "bistories gevorm" is (Du Plessis 1943(b), p. 7). 


\section{J. Du Plessis as Regsdenker}

Met die eerste oogopslag wil dit voorkom asof Du Plessis se standpunt nie wesenlik van dié van Dooyeweerd verskil nie: die resultate waartoe albei geraak, is immers min of meer dieselfde (vgl. my uiteensetting van Dooyeweerd se opvatting in Du Plessis 1978, p. 519-39). Selfs hulle oogmerke is identies, naamlik om eensdeels die natuurregtelike pretensie dat regsnorme sonder positivering deur ' $n$ histories gefundeerde vormingswil kan geld en andersdeels die positivistiese beperking van regsgelding tot die formele vorm(e) waarin regsnorme gegiet word, (albei) te oortroef (vgl. ook Dupplessis 1956/7, p. A7-8 en Dooyeweerd 1930 (b), p. 237-40, asook 1958, p. 59-61).

En tog is daar 'n verskil. Vir Dooyeweerd figureer regsbeginsels altyd teen die agtergrond van sy wetsidee-'n transendentale grondidee insake 'n wêreld of skeppingsorde ('n lex naturalis, 'n lex aeterna of 'n barmonia praestabilis) (Dooyeweerd 19691, p. 93-4). Du Plessis se opmerking teenoor Stoker (hierbo) saamgelees met sy kritiek op Dooyeweerd se té eng modale geskiedbeskouing (vgl. ook Du Plessis 1957(a) naas 1962, p. 312 ev.) open (al is dit bloot in embrio) die moontlikheid dat regsbeginsels ook in terme van 'n bistoriese denkbeeld verstaan kan word, dit wil sê nie slegs in terme van 'n oorspronklike skeppingsorde waarvan die (onder andere) differensiërende ontplooiing in terme van menslike vorming op 'n histories modale substraat verstaan moet word nie maar eweneens in terme van 'n skepping (-sorde)-op-weg, wat God self stap vir stap tot sy (ontplooiende) voleinding voer. Dit is dan ook nie verbasend nie dat Du Plessis (1962, p. 316) aanvoel dat Dooyeweerd se behandeling van die regsidee qua geregtigheidsidee - 'n idee wat in terme van menslike vorming, op basis van die historiese substraat, antisiperend tot ontplooiing gebring en dus in terme van 'n bepaalde beskawingsontwikkeling begryp moet word (vgl. bv Dooyeweerd 1938) - onbevredigend is (vgl ook my kritiek in Du Plessis 1978, p. 580-8). Onmiddellik moet egter gesê word dat Du Plessis se kritiek in hierdie verband by niks meer as 'n blote "aanvoeling" bly nie en dit is jammer. Waar hy voor 1962 oor die regsidee geskryf het, het hy Dooyeweerd feitlik kritiekloos nagevolg (vgl. bv. Du Plessis 1956/7, p. A7). Ek moet egter self "bely" dat die moontlikhede wat Du Plessis se grondbeskouings insake die geskiedenis (en sy sensitiewe historiese bewussyn) bied, my daartoe gebring het om - met die oog op die geregtigheidsprobleem - die skepping qua "bedeling" in 'n ontologies heilshistoriese perspektief te stel en aldus nuwe lig op die kwessie van regsrealisering-in-geregtigheid te verkry (vgl. Du Plessis 1978, p. 729-36). Indien my eie poging van enige waarde is, moet $L . J$ du Plessis heelwat van die krediet daarvoor kry. 


\section{Lourens M. du Plessis}

Terloops kan opgemerk word dat Stoker se kosmies dimensionele historiese visie op die reg hom daartoe bring om ook aan die "diepere" (konstitutiewe sowel as regulatiewe) ontiese reg (of "natuurreg") 'n eie geskiedenis, 'n eie voortgang, toe te skryf, sodat regsvorming (insluitend die vorming van regverdige reg) deur hom nie slegs in terme van 'n "oorspronklike skepping" verstaan word nie maar mede as 'n histories dinamiese gegewe-in-voortgang (vgl. Stoker 1970 (a), p. 62-3). In hierdie opsig dink ek dat Stoker baie naby kom aan dit wat Du Plessis in beginsel voorsien.

Du Plessis se geskiedbeskouing rus op bepaalde (al is dit sistematies-teoreties nog vae) ontologiese fondamente. Hierdie syns- en struktuurtipiese momente is vir hom egter sekondêr (Du Plessis 1957(a), p. 145), en miskien juis daarom gee hy nie uitvoerige aandag daaraan nie. Eerder wil hy sy grondbeskouing in terme van "werklike dinge en mense, stof, energie, bloed, lewe, drang en daad" konkretiseer - soos Potgieter (1972, p 141-63) op 'n bekwame wyse aantoon. En ook dit het vir sy regsbeskouing bepaalde implikasies. Om hierdie implikasies te begryp moet kortliks aandag aan sy siening op die sosiale gegee word, en daarna moet die korrelasie tussen die historiese en die sosiale soos in 'n sosiaal-eskatologiese verband omvat - ondersoek word..

\subsection{Die sosiale by Du Plessis}

Uit sy kritiek op Dooyeweerd (kyk aanhangsel) blyk dit dat Du Plessis die sosiale dimensioneel eerder as modaal wil opvat. Dooyeweerd se bespreking van die sosiale qua modaliteit tot bloot die terrein van etiket, fatsoenlikheid, mode ensovoorts bevredig L. J. du Plessis glad nie (vgl ook Du Plessis 1957 (a)). Soms ontstaan die indruk dat Du Plessis in die rigting van ' $n$ totalitêr universalistiese sosialisme neig. So byvoorbeeld was hy 'n voorstander van 'n nasionale sosialisme in Suid-Afrika (Potgieter 1972, p 179-82), kan hy die waarheidsmomente in die humanistiese sosialismes (soos Nasionaal-Sosialisme, Facisme en selfs Kommunisme) waardeer (Potgieter 1972, p. 1 70-74), staan hy selfs nie totaal antiteties teenoor die noodwendige gegewenheid van sosiale revolusie nie (Potgieter 1972, p. 175-9), oorbeklemtoon hy die positiefregtelik normatiewe faset van die regsorde ( 3.3 hierbo) en is sy behandeling van die subjektiewe reg en menseregte grotendeels onafgerond en selfs onbevredigend (2.1 hierbo). Wie Du Plessis se opvatting egter as primêr sosialisties wil verstaan, tas wesenlik mis. Hy beklemtoon immers self die feit dat "die mens ... in geen samelewingskring geheel opgaan nie" (Du Plessis 1956/57, p. A9), en in sy behandeling van die verhouding staat-reg handhaaf hy deur- 


\section{J. Du Plessis as Regsdenker}

entyd die beginsel van soewereiniteit in eie kring - selfs wanneer hy op regsgebied na die staat as 'n "opperverband" verwys (Du Plessis 1934(b), p. 146; vgl. ook 3.6 hierbo).

Van fundamentele belang is ook die feit dat Du Plessis die sosialisme as 'n bistoriese noodwendigbeid beskou en daarom selfs in die "moderne, in sigself ... eensydige, relativisme" 'n "heilsame teëgif" teen die reste van gesagsabsolutisme in die Calvinisme sien (Du Plessis 1934 (b), p. 142)! Hierdie ingrypende visie is in finale instansie in verband met Du Plessis se sosiaaleskatologiese werklikheidsvisie te verklaar.

5.3 L. J. du Plessis se sosiaal-eskatologiese werklikheidsvisie en die implikasies dasrvan vir die reg.

"Die historie is die historie van die sosiale eenwording van die mensheid met verskeidenheid in die magsintegrasie wat die tweede en volledige openbaring inlei van die liggaam van Christus, die volk van God en die Koninkryk van die Hemele, let wel, agtereenvolgens 'n biotiese, 'n kulturele en 'n politiese analogie" (Du Plessis 1962, p. 314).

In hierdie uitspraak is die kern van (die inhoud van) Du Plessis se sosiaal-eskatologiese werklikheidsvisie saamgevat: die mensdom word één met die oog op die wederkoms van Christus, maar hierdie eenheid bly 'n eenbeid in die verskeidenbeid van kultuurnasionaliteite, kultuurkringe en uiteindelik 'n internasionale wêreldkultuurgemeenskap. En hierdie éénwording van die mensdom, het regsimplikasies:

(i) Die ontwikkeling van die Westerse regs- en staatkundige geskiedenis kan alleen in terme van verskillende tydperke, elk met sy eie prinsipieel tipiese kenmerke, begryp word. Die laaste tydperk, die moderne tyd, is nomokratiesinternasionaal van aard (Du Plessis 1934 (b) en 1941 (a), p. 3-20).

(ii) Die nomokraties-internasionale karakter van die moderne tyd het op volkeregtelike gebied bepaalde implikasies. Die internasionale, tussenstaatlike maatskapreg (gebaseer op ooreenkoms) word in 'n toenemende mate 'n in 'n enkele internasionale magsoewerein gekonsentreerde (intra-) verbandsreg (gebaseer op bevel) (Du Plessis 1943 (b), p. 111-9.).

Is hierdie histories sosialiseerde "loop van dinge" na Du Plessis se mening (normatief-ideël gesproke) gewens? Ek dink nie dit is waar dit vir hom op aankom 


\section{Lourens M. du Plessis}

nie. Eerder sien hy dit as noodwendig: die oue word nuut met die oog op die finale vernuwing van 'n sugtende skepping, en 'n keuse vir die nuwe is ook 'n keuse vir God se finale vernuwing: God se tyd vir die oue gaan ook verby (Du Plessis 1945, p. 31). Omdat God self geskiedenis (ook die regsgeskiedenis) dra en omdat sowel die goeie as die slegte daarin nie buite sy wil om geskied nie, kan ons, kinders van ons tyd, met vrymoedigheid aan die tyd wat kom, behoort, terwyl ons as geborge kiners van die Vader die" ncgatiewe as gevolg van die . . sondewerking" reformerend uit die nuwe kan uitsuiwer, want die finaal nuwe bedeling is ons s'n in dié Christus wat vir seker weer kom !

In die lig van sy sosiaal-eskatologiese visie moet ten slotte ook L. J. du Plessis se besondere opvatting oor vergelding as wesenskenmerk van die reg verstaan word. Dooyeweerd (Encyclopaedie (b) ii, p. 3-4 en 1969 ii, p. 472-85) meen dat vergelding (in bonam et in malam partem), as sinkern van die juridiese bestaanswyse of modaliteit, teoreties gesproke op basis van die intuisie - qua tydelike dieptelaag van die menslike ervaring wat die logiese en a-voor-logiese fasette van die menslike denke met mekaar verbind-blootgelê word as:

"... an irreducible mode of balancing and harmonizing individual interests" (Dooyeweerd 1969 11, p. 129) dit wil sê dić synswyse waardeur “... de uiteenlopende belangen worden geharmoniseerd bij de verbinding van rechtsgevolgen aan rechtsfeiten" (Dooyeweerd Encyclopaedie (b) 11, p. 4).

Wat Dooyeweerd hier sê, geld eintlik ten opsigte van vergelding in abstracto, dit wil sê van vergelding soos (intuitief) in en deur die teoretiese denke ontwaar. Du Plessis, daarenteen, poog om vergelding deurentyd in die konkrete volheid van die (regs-) werklikheid te betrag. Vergelding staan vir hom nooit los van die konkrete "besig wees om te vergeld" in samelewingsverhoudinge nie. So verklaar hy dat die reg qua reëling daardeur gekenmerk word dat dit gedragsvereistes in die samelewing "garandeer as iets noodsaakliks, deur vergelding, d.w.s. deur die gewenste of regmatige gevolg van enige verandering in samelewingsverhoudinge te sanksioneer ..." (Du Plessis 1943(b), p. 6 ).

Teen die agtergrond van sy deurgaans konkrete (sosiaal-eskatologies gefundeerde) vergeldingsteorie moet myns insiens Du Plessis (1962, p. 315-6) se kritiek op Dooyeweerd se vergeldingsteorie beoordeel word. So byvoorbeeld verklaar hy dat Dooyeweerd oor die (aard van die) orde(s) waarbinne vergelding hom "vergeldend" voltrek, swyg, en hy vervolg dan: 


\section{J. Du Plessis as Regsdenker}

"Natuurlik hang dit (naamlik die ordenende werking van vergelding) in besonderhede af van die besondere samelewingskring en sy historiese verband, maar in die algemeen moet dit tog 'n bepaalde kenmerk hê wat meebring dat dit vergeldend gehandhaaf word. Wat kan dit wees? Hiervoor spreek Dooyeweerd hom nie uit nie" (Du Plessis 1962, p 315 - kursief my invoeging).

Deur die konkrete orde van vergelding te ignoreer konkludeer Du Plessis (1962, p. 316) behandel Dooyeweerd finaliter die regsbegrip bevredigender as die regsidee.

Oor wat sy eie vergeldingsbeskouing of, so nie, siening oor die wesensaard van die reg is, laat Du Plessis hom ongelukkig nie volledig uit nie. As ek egter kan raai, dan sou ek dink dat Stoker (1970(a), p. 64-9 en 49-50) se siening van die wesensaard van die reg as ampsbediening in korrelasie met en as konstitutief vir 'n regsorde, wat menseregte of subjektiewe regte en regsnorme in hulle onderlinge relasionaliteit omvat, L. J. du Plessis meer sou bevredig.

\section{Ten besluite}

Oor L J. du Plessis se regsbeskouing en regsdenke oor die algemeen kan nog heelwat meer gesê word. Belangrike onderwerpe moes in hierdie artikel bloot rakelings (maar hopelik darem nie lukraak nie) aangesny word. Oor ander onderwerpe, soos byvoorbeeld Du Plessis (1941(b) en 1958(b) se interessante beskouinge oor juridiese kousaliteit moes, hoe jammer dit ook al is, gewoon geswyg word.

Uiteindelik wil hierdie artikel sê dat Lodewicus Johannes du Plessis se arbeid op regsgebied, in die lig van die diepe insig van die Prediker (3:11) oor (die aard van) God se onbegryplike werk beoordeel moet word:

"Alles het Hy mooi gemaak op sy tyd; ook het $\mathrm{Hy}$ die eeu in hulle hart gelê sonder dat die mens die werk wat God doen, van begin tot end, kan uitvind".

Du Plessis het - wel wetend dat hy die finale voleinding nie in sy klaarheid kan aanskou nie - die toekoms in die geloof as 't ware oopgeskryf. En omdat hy God se konkrete heilswerk in die gang van 'n deurmekaar wêreldgeskiedenis wou deurskou, was hy 'n uitnemende voorbeeld van 'n profeet voor sy tyd! 
Aanhangsel: L J du Plessis (1962, p 309-19) se kritiek op Dooyeweerd se regsteorie

By 'n terugblik op die in die voorafgaande volledig oorskoude regsteorie van Dooyeweerd is dit in die eerste plek opvallend dat hy dit nodig gevind het om dit te baseer op ' $n$ omvattende Christelike wêreldbeskouing wat filosofies verwerk is sonder direkte verband met enige teologiese teorie: Ja, ons het gesien dat hy ten slotte selfs nie meer bereid was om sy filosofie as Calvinisties te bestempel nie - soos dit inderdaad tog is in die gees van Kuyper. [ $\mathrm{Vgl}$. in hierdie verband Dooyeweerd 1937. - L. M. Du Plessis]

Hierdie algemene filosofiese wêreldbeskouing is wel, soos alle Filosofie volgens Dooyeweerd, religieus en wel Christelik - Skriftuurlik van uitgangspunt, wat uitdruklik erken en gemotiveer word, maar dit probeer in die uitwerking die vir alle wetenskaplike ondersoekers gemeenskaplike feitlike gegewens te eerbiedig en te verklaar en alle innerlike "antinomieë" te vermy.

Trouens Dooveweerd se gedagtewisseling met denkers wat meer of minder afwyk van die Christelik-Skriftuurlike uitgangspunt, loop gow oonlik daarop uit dat hy hulle eie erkende of versweë, meer of minder humanistiese religieuse uitgangspunt blootlê en dan aanwys dat hulle daardeur in stryd kom met die feitlike "stande van sake" en tot innerlike" "antinomieë", dit wil sê wetsbotsinge weens grensoorskryding van 'n bepaalde werklikheidswetmatigheid op die terrein van 'n ander.

In hoe ver Dooyeweerd se wysgerige agtergrond bevredigend uitgewerk is, lê nie op ons weg om te beoordeel nie, hoewel dit skyn vas te staan dat daarin nog te veel (neo-) Kantiaanse invloed te bespeur is en dat dit enigsins formalisties aandoen in so ver hy fundamenteel van 'n wetsgronslag vir die kosmiese weklikheid uitgaan.

Hierdie fundering op modaliteitswette het wel vir sy regsteorie uiters vrugbaar geblyk, maar het op die teorie van ander werklikheidsaspekte blykbaar te formaliserend ingewerk, en het in die regsteorie self ook enigsins in dieselfde rigting gewerk.

Wat die eerste punt betref, is dit byvoorbeeld opmerklik dat Stoker, behalwe die modale werklikheidsaspekte onder andere ook nog fundamenteel ag dié van dinge, individueel en sosiaal, en dié van gebeurtenisse waaronder die historiese en van waardes.

En nou is dit onteenseglik dat Dooyeweerd se teorie oor die sosiale en die historiese, wat ook volgens hom so belangrik is vir die konkretisering van die juridiese, verskeie onbevredigende kante vertoon.

Wat die sosiale betref, onderskei hy eers wel 'n wetskring van die verkeer, wat hy ook sosiaal noem, maar waarvan hy sê dat daar nog geen vakwetenskap bestaan nie: hy beperk dit gewoonlik tot die gebied van fatsoen, gesel- 


\section{J. Du Plessis as Regsdenker}

ligheid, mode, takt, ensovoorts, maar lei ook die onderskeiding tussen gemeenskap en maatskap, wat in sy regsteorie so 'n belangrike rol speel, daarvan af.

Dan egter stel hy sonder verband hiermee die terrein van die verskillende samelewingsvorme, gemeenskappe en maatskappye, elke soewerein in eie kring, en gekwalifiseer deur 'n tipies-individuele modaliteitstruktuur, as studiegebied van die sosiale filosofie. Die gedetailleerde studie van elke besondere samelewingsvorm sou dan die studieveld wees van die positiewe sosiologie.

Wat die historikale betref, noem hy die sinkern hiervan eers dié van beskawingsontwikkeling en uiteindelik dié van beheersende vorming na 'n vry ontwerp. Hiervan neem hy dan wel 'n vakwetenskap aan wat byvoorbeeld 'n studie maak van historikale kultuurvorming, met progressie, differensiasie en integrasie. En hy lê 'n noue verband tussen die historikale en die juridiese, verla wat die vormingsaspek betref.

Maar oor die verband tussen die historikale en die sosiale het hy weinig te sê, terwyl bogenoemde blykbaar die historie veral die menslike samelewingsvorme betref, wat dit tot steeds meer omvattende geheel-strukture saamsnoer, totdat ons uiteindelik die stadium van die mensheidsgemeenskap sal beleef.

In hierdie verband laat Dooyeweerd ook 'n politieke. vooroordeel blyk wat waarskynlik eensdeels saamhang met 'n verset teen die nasionaal-sosialistiese totalitarisme en anderdeels met die gebrek aan nasionzliteitsbesef wat so opvallend is by hedendaagse Nederlandse intellektueles.

Want nie alleen verset hy hom teen die aangroeiende verstaatliking van die samelewingsvorme, met of sonder 'n mate van eerbiediging van die soewereiniteit in eie kring nie, maar hy toon weinig oog en hart te hê vir die kultuur. integrerende werking van die nasionaliteitsfaktor en van die nasionalisme, terwyl die nasionalisme tog 'n oorheersende faktor was in die differensiasie en die integrasie van die menslike samelewing, en die toekoms vir 'n groot deel bepaal sal word deur die mate waarin die nasionaliteite 'n selfstandige faktor sal bly in die wêreldgemeenskap.

Inderwaarheid het Dooyeweerd in sy sosiologie nie eers 'n eie staanplek vir die nasionaliteit nie: aan die een kant immers erken hy 'n primitiewe volksverband voor die moderne differensiasie; aan die ander kant ken hy ná die differensiasie as selfstandig in hierdie verband net die staat, terwyl die nasionaliteit bloot polities bepaal word, as 'n historiese gemeenskap wat neig tot selfstandige staatsvorming.

Inderdaad, in die moderne gedifferensieerde samelewing sien Dooyeweerd slegs 'n veelheid van soewereine samelewingsvorme, wat wel neig tot al verder deurgevoerde differensiasie èn integrasie, maar as integrerende faktor gee hy eint- 


\section{Lourens M. du Plessis}

lik slegs, met baie reserwes, erkenning aan die staat, terwyl hy die kultuurstuwende en kultuur-integrerende kragte misken van die historiese gemeenskappe wat die historie-vormende plek oorgeneem het van die primitiewe volksverbande en dies meer, naamlik die kultuurnasionaliteite, die kultuurkringe en die internasionale wêreldkultuurgemeenskap.

Die historie is die historie van die sosiale eenwording van die mensheid met verskeidenheid in die magsintegrasie wat die tweede en volledige openbaring inlei van die liggaam van Christus, die Volk van God en die Koninkryk van die Hemele, let wel, agtereenvolgens 'n biotiese, 'n kulturele en 'n politiese analogie.

Daarby het die reg waarlik 'n deurslaggewende rol, naamlik om die wêreldintegrasie vergeldend te bolwerk en tegelyk die verskeidenheid van kultuurkringe, nasies, sosiale groepsvorminge en individue te handhaaf in die sin van die vergelding.

Maar dit betref die konkrete stof van die histories-sosiale waarvan Dooyeweerd steeds wegskram, soos ook die geval is met sy regsbegrip self.

Met die eensydige beklemtoning van die modale, is Dooyeweerd se aandag, soos steeds, ook hier, by uitstek bepaal by die formele, die wyse of hoe van die ervaring en die bestaan.

In die geval van die reg is die ervaringswyse dan dié van die vergelding, dit wil sê dié van die herstel van 'n erkende orde deur vereffening van 'n feitlike verstewing deur 'n verpligte teëwig. Maar wat die aard van die erkende orde is, word nie gesê nie.

Natuurlik hang dit in besonderhede af van die aard van die besondere samelewingskring en sy historiese verband, maar in die algemeen moet dit tog 'n bepaalde kenmerk hê wat meebring dat dit vergeldend gehandhaaf word.

Wat kan dit wees? Hieroor spreek Dooyeweerd hom nie uit nie.

Nou is dit tog wel duidelik dat in 'n samelewingskring vergeldend opgetree sal word slegs as dit noodsaaklik is en/of noodsaaklik geag word (die momente respektiewelik van die regsbeginsel en die regspositivering); en noodsaaklik is en word normaalweg geag slegs die minimum an ordening wat in hierdie geval 'n bepaalde samelewingskring in stand kan hou en sy historiese ontwikkeling kan verseker.

Hoe dit sy, hierdie formalistiese benadering ook van die reg, bring mee dat Dooyeweerd se behandeling van die regsbegrip baie meer bevredigend is as dié van die regsidee.

Wat eersgenoemde betref, het ons so pas 'n punt van kritiek daarop genoem, en daar kan nog heelwat meer opgenoem word. Ons beperk ons nog net tot een punt. 


\section{J. Du Plessis as Regsdenker}

Dit betref naamlik die eng opvatting van die begrip subjektiewe reg. Ek kan waarlik geen rede sien waarom dit, met uitskeiding van die subjektiewe be voegdheid tot regsvorming, nie uitgebrei kan word tot alle subjektiewe bevoegdheid ten opsigte van regsgoedere en allermins waarom die regsgoedere beperk sal word tot dié met 'n ekonomiese fundering in eintlike sin, waardeur uitgesluit sou word wat ons teenswoordig onder persoonlikheidsregte verstaan nie.

Maar afgesien van hierdie en enkele ander kleiner punte van kritiek, het Dooye weerd se regsteorie omtrent die regsbegrip baie dinge in 'n helderder lig ge stel, en wel op die agtergrond van sy lewensbeskoulike onderskeiding tussen die ingeskape struktuur van en die historiese vormgewing aan allerlei regsfigure.

Laat ons eers by laasgenoemde 'n oomblik stilstaan. Die reg is vir Dooyeweerd in die eerste plek gegee in die vorm van beginsels van 'n konstante struktuur, hoewel histories beskou sommige meer staties verskyn en ander meer dinamies.

Dit is die aanrakingspunt van sy teorie met dié van die natuurreg en dié van die na-Kantse idealisme, behalwe veral dat hy die konstante beginsels nie net in die natuur (in sy sin geneem) soek soos die natuurregsteorie nie en dat hy ook die konstantheid nie toeskryf aan redelik-aprioriese subjektiewe vorming soos die Kantianisme nie.

Volgens sy wêreldbeskouing is die regsbeginsels soos die struktuur van alle dinge na hulle aard in hulle kosmiese struktuurwet gegee, terwyl hulle variable positiewe vorming in die historie plaasvind. Hier is dus plek vir evolusie in 'n beperkte sin.

Hierdie konstante struktuur is ook volgens hom nie op bonatuurlike wyse geopenbaar soos die Biblisistiese fundamentalisme wel geleer het nie, want die Bybel is van sentraal-religieuse en bo-tydelike betekenis, en in die tydelike mag niks vergoddelik word nie. Nee, dit word intuitief geken en teoreties ge sintetiseer uit ervaring van die historiese konkretiseringe daarvan.

Nou is vir die regsteorie veral die volgende konklusies uit hierdie fundamentele beskouingsw yse van besondere belang:

a. Dat die reg gegee is in beginsels ter positivering in en vir die betrokke samelewingskringe;

b. Dat die beginsels self bowillekeurig, inderdaad deur God ingeskape is, maar dat die positiewe vormgewing daaraan tot 'n mate willekeurig is, en in elk geval histories wisselend; 
Lourens M. du Plessis

c. Dat die reg deur alle samelewingsvorme gepositiveer word, maar deur die staat territoriaal geintegreer word;

d. Dat ook die staatlike reg nou besig is om internasionaal geintegreer te word in 'n wêreldreg.

\section{LITERATUURLYS}

DE WET, J. C. 1940. Die ontwikkeling van die ooreenkoms ten beboewe van 'n derde. Leiden: Sijthoff.

DIETZE, G. 1959. America and Europe - decline and emergence of judicial review. The South African Law Journal (SALJ) 76: 398-434.

DOOYEWEERD, H. 1925. Calvinisme en natuurrecht. Amersfoort: Wijngen.

- 1926. De beteekenis der wetsidee voor rechtswetenschap en rechtsphilosopbie. Kampen: Kok.

- 1928. Het juridisch causaliteitsprobleem in't licht der wetsidee. Antirevolutionaire Staatkunde (ARS) 2: 21-121.

- 1930(a). De bronnen van bet stellig recbt in be

- 1930(a). De bronnen van het stellig recht in het licht der wetsidee. $A R S 4$ : 1-67.

- 1930(b). De structuur der rechtsbeginselen en de metbode der recbtswetenschap in bet licbt der wetsidee (In Vrije Universiteit Amsterdam. Wetenschappelijke bijdragen aangeboden doorboogleeraren der Vrije Universiteit ter gelegenbeid van haar vijftigjaren bestaan. Amsterdam: NV Dagblad).

- 1933. De Theorie van de bronnen van het stellig recht. Menscb en Maatschappij 9: 340-65.

- 1935. De wijsbegeerte der wetsidee. Amsterdam-Paris 3dle.

- 1937. Wat de wijsbegeerte der wetsidee aan dr. Kuyper te danken heeft. De Reformatie 18(5): 63-5.

- 1938. Recht en historie Amsterdam: Referaat VU.

- 1958. Een nieuwe studie over het Aristotelisch begrip der gerechtigheid. Recbtsgeleerd Magazijn Themis 1958: 3-61.

- 1966. Encyclopaedie der recbtswetenscbap - Hoofdstuk $V$ Amsterdam Bureau Studentenraad VU.

- 1969. A new critique of theoretical thought. The Presbyterian and Reformed Publishing Company 4dle. 


\section{J. Du Plessis as Regsdenker}

- Encyclopaedie der rechtswetenschap (a). 2dle Amsterdam:DAVID.

- Encyclopaedie der rechtswetenschap (b) 2dle. Amsterdam: Bureau Studenteraad VU.

DUGARD, J. 1971. The judicial process, positivism and civil liberty. SALJ 88: 181-200.

DUGARD, J. 1978. Human rights and the South African legal order. Princeton: University Press.

DU PLESSIS, L.J. 1932 Die staatsteorie van Jean Calvin in verband met die wetenskap en staatspraktyk van sy tyd (Oordruk uit ARS).

- 1934(a). Konstitusionele hervorming. Koers 1 (6): 5-8.

- 1934(b). Staat en reg. Tydskrif vir Wetenskap en Kuns 12: 13350.

- 1941(a). Die moderne staat. Stellenbosch:Pro Ecclesia.

- 1941(b). Juridiese kouslaiteit. Koers 9: 22-33.

- 1943(a) Christelike hoër onderwys en die regswetenskappe. Koers 10: 172-5.

- 1943(b). Inleiding tot die algemene regsleer of jurisprudensie. S:ellenbosch: Pro Ecclesia.

- 1944. Die einde van die individualisme ook in die reg. Koers 45: 172-80.

- 1945. Die Calvinisme in sy aktualitiet gebandbaaf (In Op die voorpunt van die tye. Stellenbosch: Pro Ecclesia 29-40).

- 1956(a). Kodifikasie van ons gemene reg in die lig van die ontwerp-wetboek vir burgerlike reg in Nederland. Tydskrif vir Hedendaagse Romeins-Hollandse Reg (THRHR) 19: 257-63.

- 1956(b). 'n Konstrutief bedoelde reaksie teen skadelike repristinasies in ons regsopvattings op die gebied van staat en kerk. Koers 24: $99-105$.

- 1956(c). 'n Tentatiewe konstruktiewe reaksie op die skynbare regsbronne-teorie van die romaniste in Suid-Afrika. THRHR 19: 257-66.

- 1956/57. Diktate Regsleer. Potchefstroom: PU vir CHO (Agtercenvolgende nie-aaneenlopende bladsynumerings met $\mathrm{A}, \mathrm{B}, \mathrm{C}$ en D aangedui.)

- 1957(a). Enkele gedagtes oor die Calvinistiese sosiologie en geskiedenisfilosofie. Koers 24: 137-46. 
Lourens M. du Plessis

- 1957(b). Ons Suid-Afrikaanse regsteoretiese grondbegrippe gekonfronteer met die van prof. Dooyeweerd. Koers 25: 187-200

- 1958(a). Leemtes in Dooyeweerd se regsfilosofie. Koers 26: 10-4.

- 1958(b). The problem of causality in law. Acta Juridica 1958: 314-9.

- 1959(a). Die nuwe Franse grondwet. Koers 27: $151-5$.

- 1959(b). Die staatlike soewereiniteitsleer in die lig van die moderne Calvinistiese regsteorie. THRHR 22: 7-13.

- 1960(a). Brief aan H. G. Stoker. Manuskrip.

- 1960(b). Brief aan J. P. van der Spuy. Manuskrip.

- 1960(c). Diktate regs- en staatsleer. Potchefstroom: Pro Rege.

- 1960(d). Kommentaar op "Staatsreg" deur prof. dr. J. P. Verloren van Themaat 1956. Potchefstroom: Pro Rege.

- 1960(e). Voortsetting vergelykende regsleer by boofstuk tien. Potchefstroom: Pro Rege.

- 1960(f). Wetgewersoewereiniteit. THRHR 23: 164-73.

- 1961 (a). Brief SALJ 78: 457-9.

- 1961(b). Finale regsvergelykende. opmerkinge vir LL B 4 en 5 van 1961. Potchefstroom: Pro Regc.

- 1961(c). Regsteoretiese verskeidenbede. Klasaantekeninge.

- 1961(d). Verdere aantekeninge oor regsvergelyking vir $L L B I V$. en $\mathrm{V}$. Klasaantekeninge.

- 1961(e). Engelse proefskrif. Onvoltooide manuskrip.

- 1962. 'n Teties-kritiese ondersoek na die regsteorie van Herman Dooyeweerd in sy implikasies vir die geldende en wordende publieke reg ook met betrekking tot Suid-Afrika in sy wêreldverband. Manuskrip onvoltooide proefskrif.

- 1965. Die natuurbegrip in die Regsfilosofie. Perspektief 3(4): 5-21

Du Plessis L. M. 1974. Calvyn oor die staat en die reg. Potchefstroom: IBC reeks F2.

- 1978. Die juridiese relevansie van Christelike geregtigheid. Potchefstroom. Proefskrif.

- 1979 (a). Menseregte en konfliksituasies. Koers 44: 339-53.

- 1979 (b). 'n Menseregte-akte vir die Republiek? Woord en Daad $19(198)$ : $6-8$

FORSYTH, C. F. \& SCHILLER J. E,,(reds.) 1979. Human rights: the Cape Town Conference Kaapstad: Juta. 


\section{J. Du Plessis as Regsdenker}

HOMMES, H. J. 1969. Iets over rechtsbeginsel en Tydskrif vir Christelike Weter skap 5: 1-13.

- H. J. 1972.De elementaire grondbegrippen der rechtswetenschap. Deventer: Kluwer.

- H. J. 1976. De samengestelde grondhegrippen der recbtswetenscbap Zwolle: Tjeenk.

JOUBERT,W. A. 1958. Die realiteit van die subjektiewe reg en die betekenis van 'n realistiese begrip daarvan vir die Privaatreg THRHR 21: 12-5; 98-115.

POTGIETER,P. J. J. S. 1972. "Op die voorpunt van die tye": Hooftrekke van dic staatkundige denke van L. J. du Plessis Potchefstroom. MA-Verhandeling.

RAUBENHEIMER,J. 1961. Kollegiale administratiewe bowe in die Republiek van Suid-Afrika Potchefstroom. Proefskrif.

STOKER,H. G., 1970 (a). Die aard en rol van die reg - ' $n$ wysgerige besinning Johannesburg: Publikasiereeks van die RAU A36.

STOKER H. G., 1970 (b). Oorsprong en rigting 11. Kaapstad: Ta felberg.

VAN DER VYVER, J. D. 1973.Die juridiese funksie van staat en kerk. Durban: Butterworths.

- 1973. Die juridiese sin van die leerstuk van menseregte. Pretoria. Proefskrif.

- 1975. Die beskerming van menseregte in Suid-Afrika. Kaapstad. Juta.

- 1976. Seven lectures on buman rights. Kaapstad: Juta

VAN DER VYVER, J. D. \& VANZYL, F. J. 1972. Inleiding tot die regswetenskap. Durban: Butterworths.

VAN RENSBURG, A. D. J. 1970 Juridiese kousaliteit en aspekte van uanspreeklikheidsbeperking by die onregmatige daad. Pretoria. Proefskrif. 